\title{
CCN activity of organic aerosols observed downwind of urban emissions during CARES
}

\author{
F. Mei ${ }^{1, *}$, A. Setyan ${ }^{2, * *, * * *}$, Q. Zhang ${ }^{2}$, and J. Wang ${ }^{1}$ \\ ${ }^{1}$ Brookhaven National Laboratory, Upton, New York, USA \\ ${ }^{2}$ Department of Environmental Toxicology, University of California, Davis, California, USA \\ *now at: Pacific Northwest National Laboratory, Richland, Washington, USA \\ ** now at: Ecole Nationale Supérieure des Mines de Douai, Département Chimie \& Environnement, \\ 59508 Douai Cedex, France \\ ${ }^{* * *}$ now at: Université Lille Nord de France, 59044 Lille, France
}

Correspondence to: J. Wang (jian@bnl.gov)

Received: 23 February 2013 - Published in Atmos. Chem. Phys. Discuss.: 9 April 2013

Revised: 16 October 2013 - Accepted: 30 October 2013 - Published: 17 December 2013

\begin{abstract}
During the Carbonaceous Aerosols and Radiative Effects Study (CARES), activation fraction of size-resolved aerosol particles and aerosol chemical composition were characterized at the T1 site $(\sim 60 \mathrm{~km}$ downwind of Sacramento, California) from 10 June to 28 June 2010. The hygroscopicity of cloud condensation nuclei $(\mathrm{CCN})$-active particles $\left(\kappa_{\mathrm{CCN}}\right)$ with diameter from 100 to $170 \mathrm{~nm}$, derived from the size-resolved activated fraction, varied from 0.10 to 0.21 , with an average of 0.15 , which was substantially lower than that proposed for continental sites. The low $\kappa_{\mathrm{CCN}}$ value was due to the high organic volume fraction, averaged over $80 \%$ at the $\mathrm{T} 1$ site. The derived $\kappa_{\mathrm{CCN}}$ exhibited little diurnal variation, consistent with the relatively constant organic volume fraction observed. At any time, over $90 \%$ of the size-selected particles with diameter between 100 and $171 \mathrm{~nm}$ were $\mathrm{CCN}$ active, suggesting most particles within this size range were aged background particles. Due to the large organic volume fraction, organic hygroscopicity $\left(\kappa_{\text {org }}\right)$ strongly impacted particle hygroscopicity and therefore calculated CCN concentration. For the vast majority of the cases, an increase of $\kappa_{\text {org }}$ from 0.03 to 0.18 , which are within the typical range, doubled the calculated $\mathrm{CCN}$ concentration. Organic hygroscopicity was derived from $\kappa_{\mathrm{CCN}}$ and aerosol chemical composition, and its variations with the fraction of total organic mass spectral signal at $m / z 44\left(f_{44}\right)$ and $\mathrm{O}: \mathrm{C}$ were compared to results from previous studies. Overall, the relationships between $\kappa_{\text {org }}$ and $f_{44}$ are quite consistent for organic aerosol (OA) observed during field stud-
\end{abstract}

ies and those formed in a smog chamber. Compared to the relationship between $\kappa_{\text {org }}$ and $f_{44}$, the relationship between $\kappa_{\text {org }}$ and $\mathrm{O}: \mathrm{C}$ exhibits more significant differences among different studies, suggesting $\kappa_{\text {org }}$ may be better parameterized using $f_{44}$. A least squares fit yielded $\kappa_{\text {org }}=2.10( \pm 0.07)$ $\times f_{44}-0.11( \pm 0.01)$ with a Pearson $R^{2}$ value of 0.71 . One possible explanation for the stronger correlation between $\kappa_{\text {org }}$ and $f_{44}$ is that the $m / z 44$ signal (mostly contributed by the $\mathrm{CO}_{2}^{+}$ion) is more closely related to organic acids, which may dominate the overall $\kappa_{\text {org }}$ due to their relatively high water solubility and hygroscopicity.

\section{Introduction}

Atmospheric aerosols influence the global energy budget indirectly by changing the microphysical structure, lifetime, and coverage of clouds. An increase in aerosol concentration leads to smaller cloud droplet size and higher cloud albedo (i.e., first indirect effect; Twomey, 1977). The smaller droplet size also inhibits precipitation, leading to increases in both cloud lifetime and coverage (i.e., second indirect effect; Albrecht, 1989). Although it is generally agreed upon that indirect effects of aerosols tend to cool the Earth-atmosphere system by increasing cloud albedo, thickness, and coverage, the magnitudes of these effects are poorly understood, and the indirect effects of aerosols remain the most uncertain 
components in forcing of climate change over the industrial period (IPCC, 2007).

Understanding aerosol indirect effects requires knowledge of the ability of aerosol particles to form cloud droplets at atmospherically relevant supersaturations (i.e., CCN activity).

The cloud condensation nuclei (CCN) activity of atmospheric particles can be effectively predicted using Köhler theory (Köhler, 1936), provided that the particle size and physicochemical properties of the solute - including its molar volume, activity coefficient, and effect on surface tension - are known (McFiggans et al., 2006). Several essentially equivalent single-parameter frameworks have been proposed to model the CCN activation and hygroscopicity of multi-component aerosols (Hudson and Da, 1996; Rissler et al., 2006; Petters and Kreidenweis, 2007, 2008; Wex et al., 2007). These single-parameter frameworks combine many of the thermodynamic details necessary for the description of water activity, and provide a more streamlined approach to represent CCN activation in models. Here we use the hygroscopicity parameter $\kappa$ proposed by Petters and Kreidenweis (2007, 2008), which can be conveniently derived from sizeresolved CCN measurements. Besides droplet activation, hygroscopicity also describes particle growth under subsaturated conditions and can be derived from particle growth factor (GF) measured by a humidified tandem differential mobility analyzer (HTDMA). Previous studies suggest particles may exhibit larger $\kappa$ values for droplet activation (derived from $\mathrm{CCN}$ measurements under supersaturated conditions) than those for particle growth (derived from particle GF under subsaturated conditions) (Duplissy et al., 2008; Wex et al., 2008, 2009; Petters et al., 2009b; Good et al., 2010). In this paper, unless otherwise noted, "hygroscopicity" refers to $\kappa$ associated with droplet activation under supersaturated conditions.

The hygroscopicities of ambient inorganic species are relatively well known. In contrast, atmospheric aerosols often contain hundreds of organic species, which can contribute $\sim 20-90 \%$ to the total fine aerosol mass (Kanakidou et al., 2005; Zhang et al., 2007). A number of studies have examined the hygroscopicity of organic aerosols, including laboratory-generated organic aerosols with known composition (e.g., Raymond and Pandis, 2002, 2003; Pradeep Kumar et al., 2003; Bilde and Svenningsson, 2004; Abbatt et al., 2005; Huff-Hartz et al., 2006; Svenningsson et al., 2006), secondary organic aerosols (SOA) generated in controlled environmental chambers (Prenni et al., 2007; Duplissy et al., 2008, 2011; Asa-Awuku et al., 2009; King et al., 2009; Massoli et al., 2010; Lambe et al., 2011), and aerosols generated in laboratory biomass burning experiments (Petters et al., 2009a). A number of field studies also reported the range of $\kappa$ for the organic component of ambient aerosols (Wang et al., 2008; Shantz et al., 2008; Gunthe et al., 2009; Chang et al., 2010; Jimenez et al., 2009; Mei et al., 2013; Rose et al., 2010). Collectively, the laboratory and field studies suggest that organics have a fairly wide range of $\kappa$ values ranging from 0 to 0.3 , and $\kappa_{\text {org }}$ can increase substantially during their chemical aging in the atmosphere (Jimenez et al., 2009; Massoli et al., 2010; Duplissy et al., 2011; Lambe et al., 2011; Mei et al., 2013).

The sensitivity of predicted $\mathrm{CCN}$ concentration and droplet number concentration to aerosol properties, including the hygroscopicity of organic species, are examined in a number of recent studies (Rissman et al., 2004; McFiggans et al., 2006; Wang et al., 2008; Reutter et al., 2009; Ervens et al., 2010; Kammermann et al., 2010; Ward et al., 2010; Wang, 2007). While these studies all recognize the importance of particle size distribution, mixing state, and volume fraction of organics in particles, they also indicate that the predicted $\mathrm{CCN}$ concentration and droplet number concentration can be sensitive to $\kappa_{\mathrm{org}}$, and the value of $\kappa_{\mathrm{org}}$ needed to reproduce measured CCN concentration can vary substantially, and depends on the location and time of the study. Using constant $\kappa$ for organic components may lead to significant biases in predicted $\mathrm{CCN}$ concentrations and aerosol indirect forcing (Liu and Wang, 2010). On the other hand, atmospheric aerosols often contain hundreds of organic species, and the hygroscopicities of many organic species are often not available. Therefore efficient parameterizations that can capture the major variation of $\kappa_{\text {org }}$ are essential for implementation in large-scale models. One promising idea is that the $\kappa_{\text {org }}$ under both supersaturated and subsaturated conditions may be parameterized based on the organic oxidation level (e.g., O : C atomic ratio), which can be measured by aerosol mass spectrometers (Aiken et al., 2008) and other techniques. For particle hygroscopic growth under subsaturated conditions, measurements from TDMA show that $\kappa_{\text {org }}$ increases with O:C for a number of organic aerosols (Jimenez et al., 2009; Duplissy et al., 2011). Positive correlations between $\kappa_{\text {org }}$ and $\mathrm{O}: \mathrm{C}$ were also found under supersaturated conditions for SOA and oxidized POA generated in a Potential Aerosol Mass (PAM) flow reactor (Massoli et al., 2010; Lambe et al., 2011), and ambient organic aerosols observed at rural (Chang et al., 2010) and urban (Mei et al., 2013) sites. At present, the data on the hygroscopicity of ambient organics are still quite limited (Lathem et al., 2013; Moore et al., 2011), and the relationship between $\kappa_{\text {org }}$ and organic oxidation level needs to be examined for ambient aerosols from representative organic aerosol sources before it can be confidently implemented in climate models. In this paper we report particle hygroscopicity and mixing state derived from size-resolved CCN measurements carried out during the Carbonaceous Aerosol and Radiative Effects Study (CARES). The impact of $\kappa_{\text {org }}$ on predicted CCN spectrum was examined. Organic hygroscopicity was derived from particle hygroscopicity and chemical composition, and its relationship to organics oxidation level is discussed. 


\section{Experimental method}

\subsection{Measurement site}

The Carbonaceous Aerosol and Radiative Effects Study was a field campaign focusing on the evolution of secondary organic and black carbon (BC) aerosols and their climaterelated properties in the Sacramento urban plume as it was routinely transported into the forested Sierra Nevada foothills area (Zaveri et al., 2012). Aerosol measurements were taken from 2 June to 28 June 2010 at the T1 site, which was located about $60 \mathrm{~km}$ to the northeast of Sacramento in Cool, CA, a small town situated amidst a forested area rich in biogenic emissions (latitude: 38.87; longitude: -121.02 ; altitude: $\sim 460 \mathrm{~m}$ m.s.l.). The data related to the analysis presented in this paper were available from 10 June to 28 June. Aerosol data included aerosol size distribution, chemical composition, $\mathrm{CCN}$ spectrum (as a function of supersaturation), size-resolved CCN spectrum and activated fraction, all of which were taken at the ground level. All measurements are reported at ambient conditions and local time (UTC time minus $7 \mathrm{~h}$ ) is used throughout this study.

\subsection{Size-resolved CCN activated fraction and total $\mathrm{CCN}$ spectrum}

The measurement of size-resolved CCN activated fraction is detailed in Mei et al. (2013) and is briefly described here. Ambient aerosol was first dried to below $20 \%$ relative humidity and neutralized by a $\mathrm{Kr}-85$ aerosol neutralizer, and subsequently classified by a differential mobility analyzer. The classified aerosol was then simultaneously characterized by a condensation particle counter and a CCN counter (Roberts and Nenes, 2005; Lance et al., 2006; Rose et al., 2008). During CARES, the sample and sheath flows of the DMA were maintained at 0.8 and $8 \mathrm{~L} \mathrm{~min}^{-1}$, respectively. The total flow of CPC was reduced to $0.5 \mathrm{~L} \mathrm{~min}^{-1}$ and the sample flow of the $\mathrm{CCN}$ counter was maintained at $0.3 \mathrm{~L} \mathrm{~min}^{-1}$. The measurement sequence is illustrated in Fig. S1 (Supplement). The longitudinal temperature gradients of the CCN counter was stepped through 4.5, 5.5, 6.5, 8, $10,12{ }^{\circ} \mathrm{C}$ (Fig. S1b). Based on calibrations using ammonium sulfate particles, the corresponding supersaturations $(S)$ derived from Köhler theory using a constant van't Hoff factor of 2.5 were $0.15 \%, 0.19 \%, 0.23 \%, 0.30 \%, 0.39 \%$ and $0.45 \%$, respectively. The supersaturation inside the $\mathrm{CCN}$ counter was maintained at each value for approximately $40 \mathrm{~min}$, during which the diameter of particles classified by the DMA was scanned between $20 \mathrm{~nm}$ and $350 \mathrm{~nm}$ eight times (310 s per scan) (Wang and Flagan, 1990). The CCN counter was stepped through the temperature gradients in a "sawtooth" pattern (Fig. S1b), and provided measurements at the above six $S$ values approximately every $4 \mathrm{~h}$. The aerosol size distribution was derived by inverting the particle concentration measured by the CPC using a routine described in Collins et al. (2002). The same procedure was also applied to measured CCN concentration to obtain size-resolved CCN concentration. The ratio of the two provided size-resolved CCN activated fraction.

In addition to size-resolved $\mathrm{CCN}$ activated fraction, total $\mathrm{CCN}$ concentration was measured using a a second CCN counter (Droplet Measurement Technologies, Model CCN100 ) operated at a flow rate of $0.3 \mathrm{~L} \mathrm{~min}^{-1}$, and longitudinal temperature gradients of $4.0,5.5,6.6,8.1$, and $10.3^{\circ} \mathrm{C}$, which corresponded to supersaturations $0.12 \%, 0.20 \%, 0.24 \%$, $0.30 \%$, and $0.38 \%$, respectively. The temperature gradient was stepped through the five values every $30 \mathrm{~min}$ as shown in Fig. S1a.

\subsection{Chemical composition}

The concentrations of submicron non-refractory $\left(\mathrm{NR}-\mathrm{PM}_{1}\right)$ organic and inorganic (nitrate, sulfate, ammonium, chloride) aerosol species were measured using a high-resolution timeof-flight aerosol mass spectrometer (HR-ToF-AMS, Aerodyne Research Inc., hereinafter AMS for short) (DeCarlo et al., 2006). The AMS sampled from an inlet equipped with a $\mathrm{PM}_{1}$ impactor (Brechtel Manufacturing Inc., Hayward, CA; model 8003). The ambient air passed through 3 feet $(0.91 \mathrm{~m})$ of stainless steel tube with an inner diameter of $3 / 4$ inch $(1.91 \mathrm{~cm}), 8$ feet $(2.44 \mathrm{~m})$ of copper tube with an inner diameter of $1 / 4 \mathrm{inch}(0.64 \mathrm{~cm}), 2$ feet $(0.61 \mathrm{~m})$ long temperature-controlled thermodenuder, and a Nafion dryer prior to sampling by the AMS. The resulting data were averaged over $2.5 \mathrm{~min}$ intervals. All data were analyzed using standard AMS software (SQUIRREL v1.51 and PIKA v1.10) within Igor Pro 6.2.2.2 (Wave Metrics, Lake Oswego, OR). Details of the AMS operation, data treatment, positive matrix factorization (PMF) analysis, and data interpretation are given elsewhere (Setyan et al., 2012).

\section{Diurnal variations of aerosol properties}

Diurnal variations of aerosol properties observed from 10 June to 28 June 2010 are shown in Fig. 1, including aerosol particle size distribution (Fig. 1a), species mass concentrations measured by the AMS (Fig. 1b), derived volume fractions of major species (Fig. 1c), and measured CCN concentrations (Fig. 1d). Sulfate and nitrate were essentially neutralized by ammonium in the CCN-relevant sizes (Setyan et al., 2012). The volume fractions of major species were calculated using densities of organics $\left(1.25 \mathrm{~g} \mathrm{~cm}^{-3}\right)$, ammonium sulfate $\left(1.77 \mathrm{~g} \mathrm{~cm}^{-3}\right)$, ammonium nitrate $\left(1.72 \mathrm{~g} \mathrm{~cm}^{-3}\right)$, and $\mathrm{BC}\left(1.8 \mathrm{~g} \mathrm{~cm}^{-3}\right)$. The mass concentration of BC was typically less than $0.1 \mu \mathrm{g} \mathrm{m}^{-3}$, contributing to less than $2 \%$ of the total submicron aerosol volume (not shown). High number concentration $\left(N_{\mathrm{CN}}\right)$ of Aitken mode particles was often observed in the afternoon between 12:00 and 18:00, and is attributed to early morning traffic-hour pollution transported 
from downtown Sacramento (Setyan et al., 2012). The mass concentration of sulfate and organics showed a relatively modest increase $(\sim 30 \%$ over otherwise nearly constant background) during this period. However, the species volume fractions were relatively constant during the day. Among all the species, organics had by far the largest contribution to the total submicron aerosol volume, at $\sim 85 \%$. The contributions from sulfate and nitrate were only $\sim 10 \%$ and $\sim 5 \%$, respectively. On average, $\mathrm{CCN}$ concentrations measured at $0.12 \%$ and $0.38 \%$ supersaturations were $\sim 120$ and $\sim 1000 \mathrm{~cm}^{-3}$. No significant diurnal trends in measured $\mathrm{CCN}$ concentrations were observed, suggesting most particles transported from the Sacramento area observed between 12:00 and 18:00 were not effective $\mathrm{CCNs}$ under measured supersaturations. This was likely due to the combination of the relatively small particle size (a majority of the particles transported to T1 during 12:00-18:00 were smaller than $50 \mathrm{~nm}$ in diameter) and particle compositions dominated by organics that in general are significantly less hygroscopic than inorganic salts such as sulfate.

\section{Methods}

\subsection{Derivation of particle hygroscopicity and mixing state}

The derivation of particle hygroscopicity $\kappa$ and mixing state was detailed in Mei et al. (2013) and is briefly described here. The activated fraction of size-selected particles $\left(R_{\mathrm{a}}\right)$ typically increased with increasing supersaturation, and eventually reached a plateau, which gives the maximum activated fraction $(E)$. The difference between $100 \%$ and $E$ represents the number fraction of particles consisting of only nonhygroscopic species (e.g., BC) that cannot serve as CCN under typical atmospheric supersaturations. The characteristic critical supersaturation $\left(S^{*}\right)$ of the size-selected $\mathrm{CCN}$ is the supersaturation at which $R_{\mathrm{a}}$ reaches $50 \%$ of $E$. The variation of $R_{\mathrm{a}}$ as a function of $S$ was fitted using both a sigmoid function (Lance, 2007; Cerully et al., 2011; Bougiatioti et al., 2011; Padro et al., 2012; Lance et al., 2013; Mei et al., 2013) and a lognormal function (Mei et al., 2013), with $E$ and $S^{*}$ among fitting parameters. For each set of measurements, the function form that yielded the best fit (i.e., smaller least squares residue) was employed for subsequent analysis. The probability density function of the critical supersaturation for the size-selected CCN was derived by differentiating the fitted $R_{\text {a }}$ with respect to $S$ (Supplement). The density function was then used to calculate the dispersion of CCN hygroscopicity by taking into consideration the width of DMA transfer function (Mei et al., 2013; Lance et al., 2013). The dispersion of CCN hygroscopicity, which reflects the chemical heterogeneity of activated particles, is defined as $\sigma(\kappa) / \bar{\kappa}$, where $\sigma(\kappa)$ and $\bar{\kappa}$ are the standard deviation and the average of the
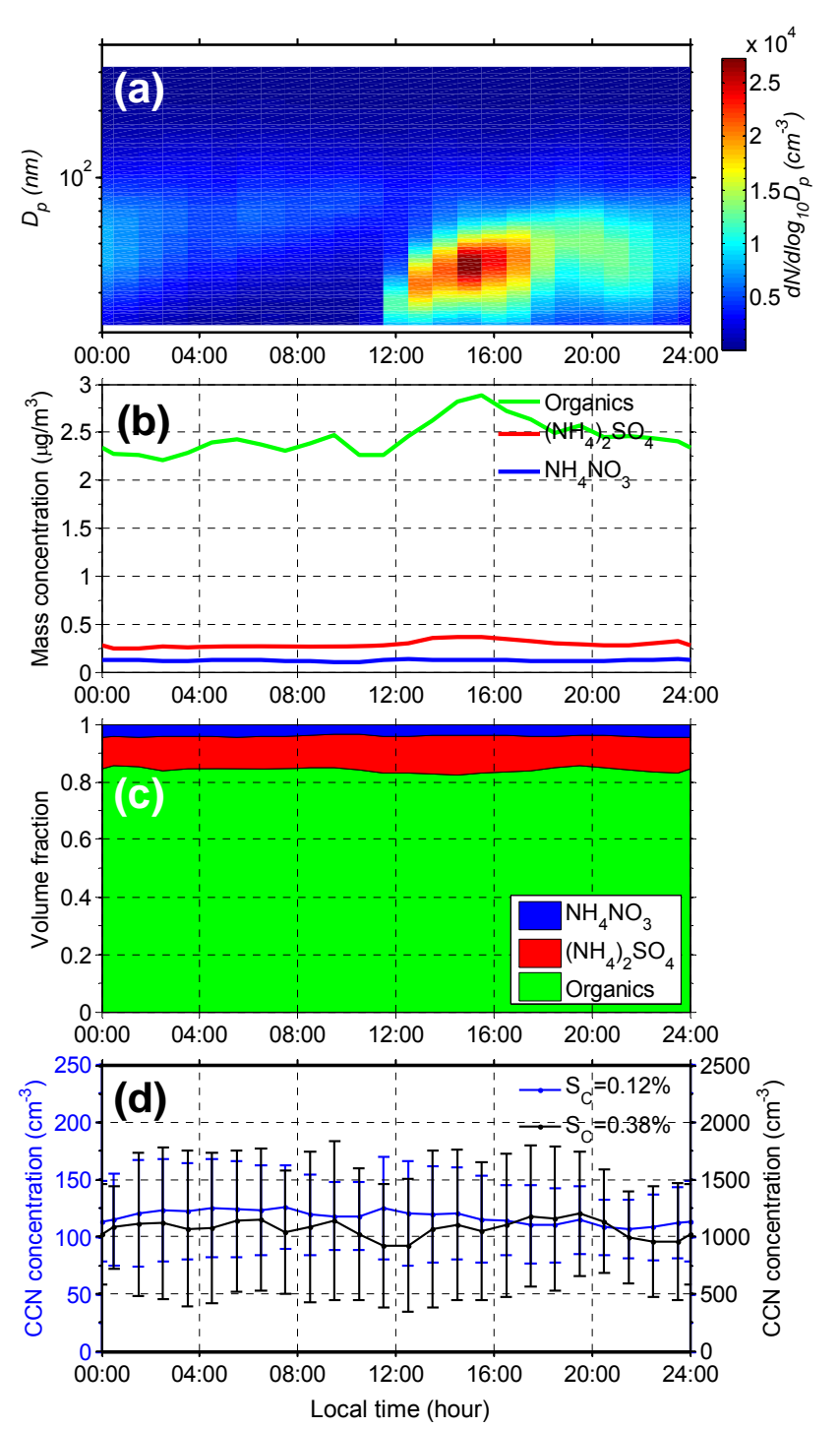

Fig. 1. Diurnal variations of aerosol properties observed at the T1 site from 10 June to 28 June 2012. (a) Aerosol size distribution; (b) mass concentrations and (c) volume fractions of organics, $\left(\mathrm{NH}_{4}\right)_{2} \mathrm{SO}_{4}$, and $\mathrm{NH}_{4} \mathrm{NO}_{3}$; and (d) $\mathrm{CCN}$ concentrations measured at supersaturations of $0.12 \%$ and $0.38 \%$.

CCN hygroscopicity, respectively (Mei et al., 2013). The details of the derivations are also given in the Supplement.

\subsection{Derivation of organic hygroscopicity and its uncertainty}

Measurements from AMS show the composition of submicron particles was dominated by organics, followed by ammonium, sulfate, and nitrate (Fig. 1). The contribution of chloride was negligible, and the analysis of anion and cation balance suggests that anionic species $\left(\mathrm{NO}_{3}^{-}, \mathrm{SO}_{4}^{2-}\right)$ were neutralized by $\mathrm{NH}_{4}^{+}$over the relevant size range of $\mathrm{CCN}$ measurements (Setyan et al., 2012). For refractory species, 
$\mathrm{BC}$ represented a negligible fraction of the total submicron aerosol volume (i.e., less than $2 \%$ ), and the contribution of sea salt and dust are also expected to be negligible for the size range of interest (i.e., less than $300 \mathrm{~nm}$ ) at the $\mathrm{T} 1$ site. Therefore, aerosols within the size range examined were assumed consisting of the following three species: organics, $\left(\mathrm{NH}_{4}\right)_{2} \mathrm{SO}_{4}$, and $\mathrm{NH}_{4} \mathrm{NO}_{3}$. We note that a fraction of nitrate observed was organonitrate or metal nitrate (Setyan et al., 2012). However, as nitrate only represented $\sim 3.5 \%$ of total non-refractory $\mathrm{PM}_{1}$, assuming nitrate as $\mathrm{NH}_{4} \mathrm{NO}_{3}$ should not substantially affect derived $\kappa_{\text {org }}$ values. During CARES, $E$ observed at the T1 site was mostly very close to $100 \%$ (the minimum $E$ was $92 \%$ during the periods chosen for deriving $\kappa_{\text {org }}$ as described below). Therefore, particles were assumed as internal mixtures, and the particle hygroscopicity is therefore the volume average of the three participating species:

$$
\begin{aligned}
\kappa_{\mathrm{CCN}} & =\sum_{i} x_{i} \kappa_{i}=x_{\mathrm{org}} \kappa_{\mathrm{Org}}+x_{\left(\mathrm{NH}_{4}\right)_{2} \mathrm{SO}_{4}} \kappa_{\left(\mathrm{NH}_{4}\right)_{2} \mathrm{SO}_{4}} \\
& +x_{\mathrm{NH}_{4} \mathrm{NO}_{3}} \kappa_{\mathrm{NH}_{4} \mathrm{NO}_{3}},
\end{aligned}
$$

where $x_{i}$ is the volume fraction of species $i$. The values of $\kappa$ are 0.67 and 0.61 for $\left(\mathrm{NH}_{4}\right)_{2} \mathrm{SO}_{4}$ and $\mathrm{NH}_{4} \mathrm{NO}_{3}$, respectively. The hygroscopicity of $\mathrm{CCN}\left(\kappa_{\mathrm{CCN}}\right)$ can be derived from $S^{*}$ :

$\kappa_{\mathrm{CCN}}=\frac{4 A^{3}}{27 D_{\mathrm{p}}^{3}\left(S^{*}\right)^{2}}$,

and the organic hygroscopicity $\kappa_{\text {org }}$ is given by subtracting the contribution of the other species from the overall $\mathrm{CCN}$ hygroscopicity:

$$
\begin{aligned}
& \kappa_{\text {org }}=\frac{1}{x_{\text {org }}}\left(\kappa_{\mathrm{CCN}}-\kappa_{\mathrm{NH}_{4} \mathrm{NO}_{3}} x_{\mathrm{NH}_{4} \mathrm{NO}_{3}}\right. \\
& -\kappa_{\left(\mathrm{NH}_{4}\right)_{2} \mathrm{SO}_{4}} x_{\left.\left(\mathrm{NH}_{4}\right)_{2} \mathrm{SO}_{4}\right)},
\end{aligned}
$$

The derivation of $\kappa_{\mathrm{org}}$ requires the volume fraction of $\left(\mathrm{NH}_{4}\right)_{2} \mathrm{SO}_{4}$ and $\mathrm{NH}_{4} \mathrm{NO}_{3}$ of $\mathrm{CCN}$ at selected sizes, which were derived from size-resolved AMS measurements (particle time-of-flight "PToF" mode) as detailed below. AMS measurements were averaged over periods, during which chemical composition was essentially constant, to increase signal-to-noise ratios (SNR). Species volume fractions at each size were then derived from mass concentrations and densities of participating species. Based on the $\mathrm{O}: \mathrm{C}$ and $\mathrm{O}: \mathrm{H}$ atomic ratios during the periods, organics were assumed to have a density of $1250 \mathrm{~kg} \mathrm{~m}^{-3}$ (Kuwata et al., 2012). The volume fractions required to derive $\kappa_{\text {org }}$ from Eq. (3) were then calculated by combining the volume concentrations of organics, sulfate, and nitrate. In this study, $\kappa_{\text {org }}$ was derived based on hygroscopicity of CCN classified at five sizes ranging from 117 to $160 \mathrm{~nm}$ at which both the counting statistics of size-resolved $\mathrm{CCN}$ measurements (based on aerosol number) and the signal-to-noise ratio of the AMS measurements (aerosol mass based) were sufficient.

\subsection{Uncertainty analysis for organic hygroscopicity derivation}

Based on Eq. (2), the uncertainty in derived $\kappa_{\text {org }}$ can be attributed to the uncertainties in $\kappa_{\mathrm{CCN}}$ and species volume fractions of $\mathrm{CCN}$. The derivation of the uncertainty is detailed in Mei et al. (2013). As the contribution of BC to submicron aerosol mass is negligible, the uncertainty of derived $\kappa_{\text {org }}$ is simplified to

$$
\begin{gathered}
\sigma_{\kappa_{\text {org }}}^{2}=\left(\frac{\kappa_{\mathrm{CCN}}}{x_{\text {org }}}\right)^{2}\left(\frac{\sigma_{\kappa_{\mathrm{CCN}}}}{\kappa_{\mathrm{CCN}}}\right)^{2}+\left(\kappa_{\text {inorg }}-\kappa_{\mathrm{org}}\right)^{2}\left(1-x_{\mathrm{org}}\right)^{2} \\
{\left[\left(\frac{\sigma_{v_{\text {org }}}}{v_{\text {org }}}\right)^{2}+\left(\frac{\sigma_{v_{\text {inorg }}}}{v_{\text {inorg }}}\right)^{2}\right]}
\end{gathered}
$$

where $v_{i}$ represents the volume concentration of species $i$, and $\kappa_{\text {inorg }}$ is the average hygroscopicity of the particle inorganic component, which included $\left(\mathrm{NH}_{4}\right)_{2} \mathrm{SO}_{4}$ and $\mathrm{NH}_{4} \mathrm{NO}_{3}$. For the derivation of the uncertainty in $\kappa_{\text {org }}$, a constant value of 0.64 was used for $\kappa_{\text {inorg }}$ (Mei et al., 2013).

The first term on the right-hand side (RHS) of Eq. (4) is associated with the uncertainty in derived $\kappa_{\mathrm{CCN}}$ (i.e., $\frac{\sigma_{\kappa_{\mathrm{CCN}}}}{\kappa_{\mathrm{CCN}}}$ ), which is due to the accuracy of the dry size of particles classified by the DMA (Wang et al., 2003) and $S^{*}$ derived from size-resolved CCN measurements. This uncertainty was estimated ranging from 5\% to $12 \%$ (Mei et al., 2013). The second term on the RHS of Eq. (4) represents contributions due to the uncertainties in volume fractions of organics and inorganics (i.e., particle composition), derived from the mass concentrations measured by AMS and the densities of the species. For the purpose of estimating uncertainty in species volume fraction, an uncertainty of $10 \%$ was estimated for inorganic and organic volume concentrations, which were mainly due to the uncertainties in relative ionization efficiencies of AMS (Mei et al., 2013). Based on Eq. (4), both terms of the uncertainty decrease strongly with increasing $x_{\text {org }}$. Therefore, the derivation of $\kappa_{\text {org }}$ was focused on periods with organic volume fraction higher than $60 \%$ (Mei et al., 2013).

\section{Results}

\subsection{Hygroscopicity of activated particles}

The hygroscopicity of size-selected CCN with diameter between 100 and $171 \mathrm{~nm}$ ranged from 0.10 to 0.2 , with an average of 0.15 , in agreement with the results derived from CCN measurements over Sacramento valley onboard NOAA WP-3D during California Nexus (CalNex; Moore et al., 2012). The hygroscopicity range was substantially lower than that proposed for continental sites (Andreae and Rosenfeld, 2008), likely due to the higher volume fraction of organics. The hygroscopicity of size-selected particles was averaged for sizes ranging from 100 to $171 \mathrm{~nm}$, and its diurnal 
variation is shown in Fig. 2a. Median and mean hygroscopicities were essentially the same, and both showed a very narrow range from 0.13 to 0.16 . There was no significant diurnal trend in the statistics of $\kappa_{\mathrm{CCN}}$, consistent with relatively constant organic volume fraction during the day (Fig. 1). Figure $2 b$ shows the diurnal variation of $E$, which represents the fraction of classified particles that were $\mathrm{CCN}$-active. Unlikely earlier studies in the urban environment (i.e., near major aerosol sources), where $E$ decreased to $\sim 70 \%$ or lower during morning traffic hours (Lance et al., 2013; Padro et al., 2012; Mei et al., 2013), the $E$ observed at the T1 site was greater than $90 \%$ essentially at all times, suggesting vast majority of particles within the 100-171 nm range were aged background particles. The average dispersion was 0.29 , substantially lower than those observed in the urban environment (Su et al., 2010; Padro et al., 2012). The lower value of dispersion reflects more aged aerosols observed at the T1 site, and is consistent with the finding that aerosol composition becomes increasingly more homogeneous as particles age through coagulation and condensation of secondary species (Mei et al., 2013; Wang et al., 2010). The diurnal variation showed lower dispersion in later morning and afternoon, and is attributed to stronger SOA production during the period and subsequent condensation on existing particles.

\subsection{Impact of organic hygroscopicity on calculated CCN concentration}

The impact of $\kappa_{\text {org }}$ on calculated $\mathrm{CCN}$ concentration $\left(N_{\mathrm{CCN}}\right)$ was examined using the following approach. $\mathrm{CCN}$ concentrations were calculated using four representative $\kappa_{\text {org }}$ values, $0.03,0.08,0.13$, and 0.18 , which are within the typical range based on earlier laboratory studies (e.g., Prenni et al., 2007; Duplissy et al., 2008; Engelhart et al., 2008; Wex et al., 2009). Aerosol particles were assumed as internal mixtures, as suggested by the observed low hygroscopicity dispersion and close-to-unity $E$ value for the size-selected particles. Based on this assumption, particle hygroscopicity was derived as the volume average of the following three species: $\left(\mathrm{NH}_{4}\right)_{2} \mathrm{SO}_{4}, \mathrm{NH}_{4} \mathrm{NO}_{3}$ and organics. On average, the aerosol mass concentration measured by the AMS at the T1 site peaked around $200 \mathrm{~nm}$ (vacuum aerodynamic diameter, $\sim 160 \mathrm{~nm}$ for mobility or volume average diameter assuming spherical particles), and minor variation in organic volume fraction was observed from 100 to $200 \mathrm{~nm}$ (vacuum aerodynamic diameter), which corresponds to a critical supersaturation range of $\sim 0.14 \%$ to $\sim 0.4 \%$. Therefore, for the purpose of examining the sensitivity of calculated $N_{\mathrm{CCN}}$ to $\kappa_{\mathrm{org}}$, particle hygroscopicity was computed from the bulk composition (i.e., derived from AMS MS mode measurements) using Eq. (1). Based on the particle hygroscopicity and $\kappa$ Köhler theory, the critical dry particle activation diameter $\left(D_{\mathrm{pc}}\right)$ was derived for the five supersaturations under which the total $\mathrm{CCN}$ concentrations were measured. The $N_{\mathrm{CCN}}$ at the five
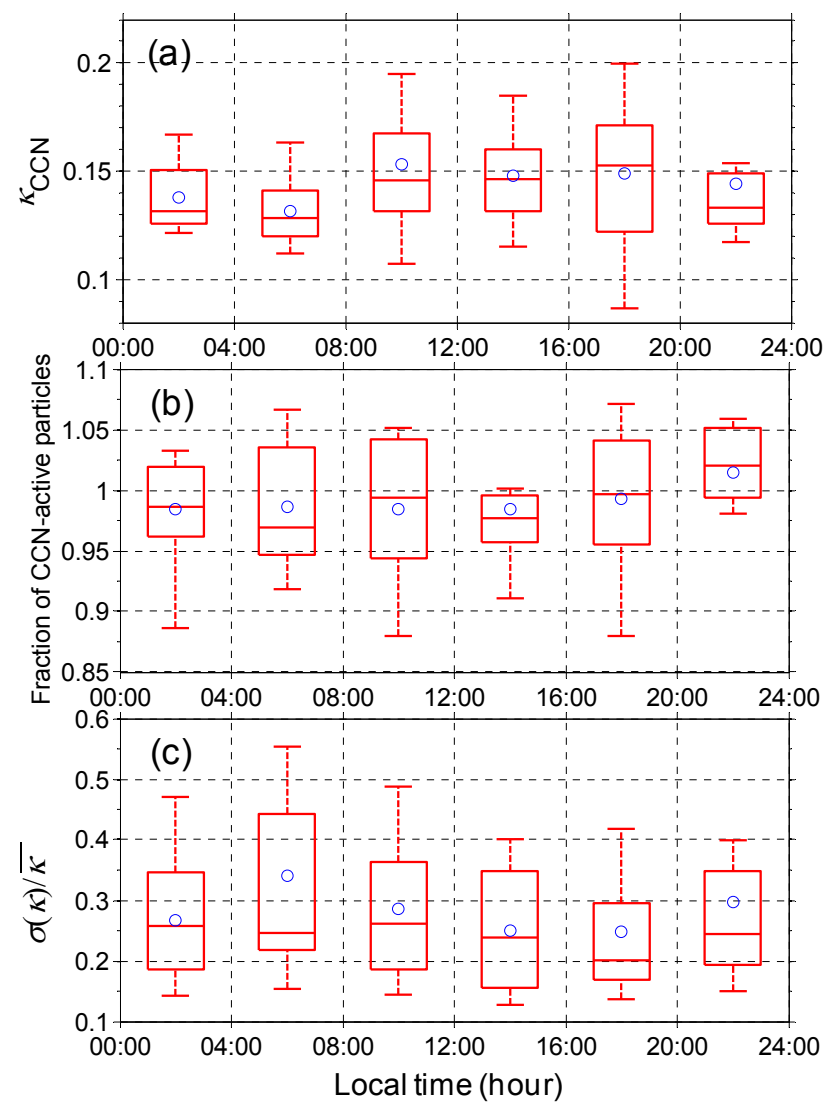

Fig. 2. The diurnal variations of (a) the average hygroscopicity, (b) maximum activation fraction, and (c) dispersion of size-selected $\mathrm{CCN}$ active particles ranging from 100 to $171 \mathrm{~nm}$. The ends of the whiskers represent the minimum and maximum of data except for the outlines, which are defined as points outside of $\pm 2.7 \sigma$. The bottom and the top of the box are the 25th and 75th percentiles, the line inside the box is the 50th percentile, and the blue circle represents the mean value.

supersaturations were then computed from $D_{\mathrm{pc}}$ and the measured dry particle size distributions.

The comparison of calculated $N_{\mathrm{CCN}}$ and that measured at three supersaturations, $0.12 \%, 0.23 \%$, and $0.38 \%$, are shown in Fig. 3 (comparison at the other two supersaturations are similar and not shown). When $x_{\text {org }}$ was greater than $90 \%$, calculated $N_{\mathrm{CCN}}$ was very sensitive to $\kappa_{\text {org }}$ values, especially at lower supersaturations. The ratio of calculated to measured $N_{\mathrm{CCN}}$, derived through a bivariate least squares fit (i.e., orthogonal distance regression), increased from 0.75 by almost $200 \%$ to 2.08 when $\kappa_{\text {org }}$ increased from 0.03 to 0.18 . Each incremental increase of $0.05 \mathrm{in} \kappa_{\mathrm{org}}$, which is well within the range of organic hygroscopicity reported in literature, led to $\sim 40-50 \%$ increase in the calculated $N_{\mathrm{CCN}}$. At the higher supersaturation of $0.38 \%$, the difference between $N_{\mathrm{CCN}}$ calculated using the different $\kappa_{\text {org }}$ values reduced somewhat to about a factor 2 (i.e., ratio increased from 0.58 to 1.10 ), but was still very significant. This reduced 
$S=0.12 \%$
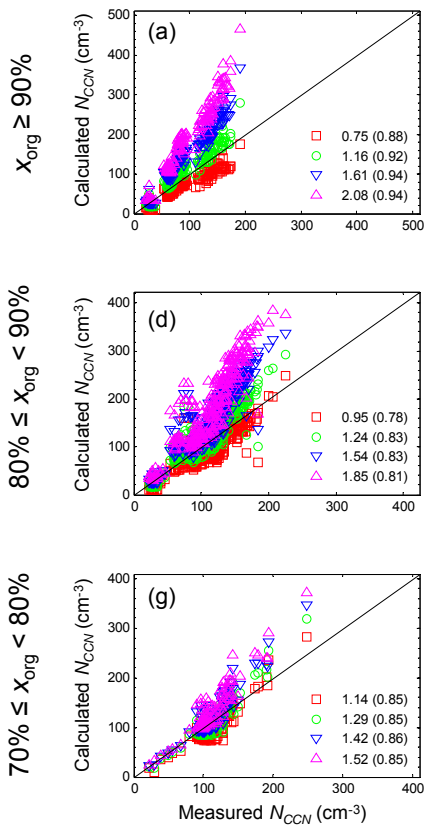

$\square \kappa_{\mathrm{org}}=0.03$
$S=0.23 \%$
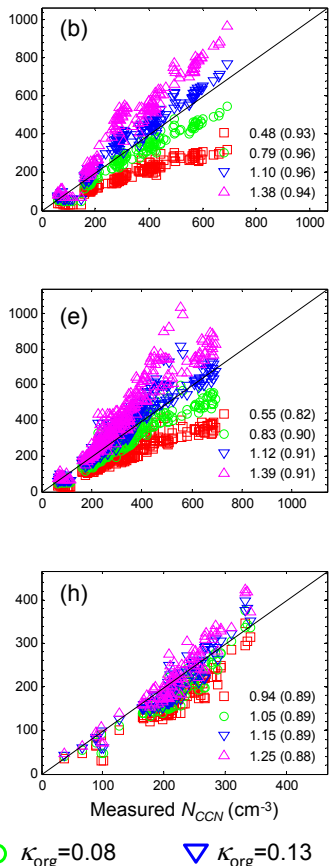

$S=0.38 \%$
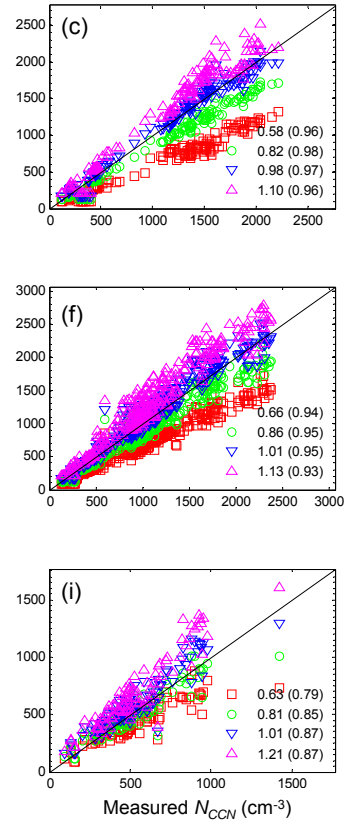

$\triangle \kappa_{\text {org }}=0.18$

Fig. 3. Comparison of $N_{\mathrm{CCN}}$ calculated using four different $\kappa_{\mathrm{org}}$ values and the measurements at supersaturations of $0.12 \%$ (a, d, g), $0.23 \%$ $(\mathbf{b}, \mathbf{e}, \mathbf{h})$, and $0.38 \%(\mathbf{c}, \mathbf{f}, \mathbf{i})$ for cases when $x_{\mathrm{org}}>90 \%(\mathbf{a}, \mathbf{b}, \mathbf{c}), 80 \%<x_{\mathrm{org}}<90 \%(\mathbf{d}, \mathbf{e}, \mathbf{f})$, and $70 \%<x_{\mathrm{org}}<80 \%$ (g, h, and i). The slope (left, derived through a bivariate least squares fit) and the $R^{2}$ value (in the parenthesis) are shown for all assumed $\kappa_{\text {org }}$ values in each plot. The solid black line corresponds to the $1: 1$ line.

sensitivity was due to the fact that a larger fraction of particle population was already $\mathrm{CCN}$ active at higher $S$. The sensitivity also strongly depended on the $x_{\text {org }}$. For example, when $80 \%<x_{\mathrm{org}}<90 \%, N_{\mathrm{CCN}}$ calculated at $S=0.12 \%$ increased by $\sim 100 \%$ (i.e., ratio increased from 0.95 to 1.85 ) while $\kappa_{\text {org }}$ increased from 0.03 to 0.18 , compared to nearly a factor of 3 increase when $x_{\text {org }}$ was greater than $90 \%$, and the increase was further reduced to $\sim 40 \%$ (i.e., the ratio increased from 1.14 to 1.52 ) when $70 \%<x_{\text {org }}<80 \%$. For most of the measurements, the $\kappa_{\text {org }}$ value required for an agreement between calculated and measured $N_{\mathrm{CCN}}$ ranged from 0.03 to 0.15 , in agreement with $\kappa_{\text {org }}$ derived from size-resolved CCN measurements described below.

During CARES, aerosols observed at the T1 site were dominated by organics. For the comparison described above, $24 \%, 54 \%$, and $16 \%$ of the data points corresponded to $x_{\text {org }}>90 \%, 80 \%<x_{\text {org }}<90 \%$, and $70 \%<x_{\text {org }}<80 \%$, respectively. Only $6 \%$ of data points were associated with $x_{\text {org }}$ less than $70 \%$. The decreasing sensitivity of the calculated $N_{\mathrm{CCN}}$ to $\kappa_{\text {org }}$ is in agreement with earlier studies (e.g., Chang et al., 2007; Wang et al., 2008). When $x_{\text {org }}$ is less than $\sim 60 \%$, the overall hygroscopicity of internally mixed particles is dominated by inorganic species such as sulfate and nitrate, which have significantly higher $\kappa$ values than organic compounds. As a result, the particle hygroscopic- ity, and therefore the calculated $\mathrm{CCN}$ concentration, is relatively insensitive to $\kappa_{\text {org }}$. When $x_{\text {org }}$ reaches $80 \%$ or higher, the contribution of $\kappa_{\text {org }}$ begins to dominate the overall particle hygroscopicity, and the value of $\kappa_{\text {org }}$ strongly influences the calculated $N_{\mathrm{CCN}}$. With stricter control of sulfur emission, aerosol organic fraction is likely to increase in the future. Therefore, simulated $N_{\mathrm{CCN}}$ will likely exhibit a stronger dependence on $\kappa_{\text {org }}$ values when projecting future climate change. This again suggests the necessity of better understanding $\kappa_{\text {org }}$ and its variation in the atmosphere for accurate prediction of $N_{\mathrm{CCN}}$ and aerosol indirect effects.

\section{$5.3 \kappa_{\text {org }}$ derived from measurements at CARE T1 site and comparison with previous studies}

To increase SNR and reduce the uncertainty in derived $\kappa_{\mathrm{org}}$, we averaged measurements over periods during which particle chemical composition essentially remained constant (i.e., the difference between the maximum and minimum of organic volume fraction was less than $10 \%$ ). A total of 18 such periods with average bulk organic volume fraction greater than $60 \%$ were identified, and ranged from 7.6 to $14 \mathrm{~h}$. These periods were approximately evenly distributed diurnally, and the total time was $\sim 9$ days, representing $\sim 50 \%$ of the total sampling time. During these periods, $E$ was greater than $96 \%$, and $\sigma(\kappa) / \bar{\kappa}$ was less than 0.3 , indicating the 

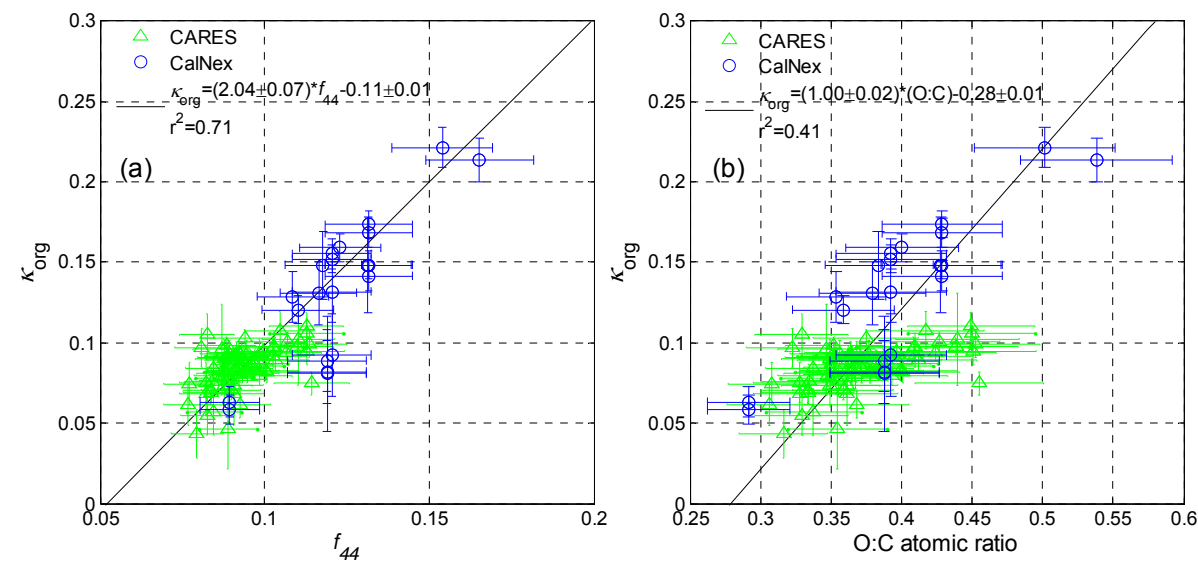

Fig. 4. Derived $\kappa_{\text {org }}$ as a function of (a) $f_{44}$ and (b) $\mathrm{O}: \mathrm{C}$ atomic ratio and least squares fits.

assumption of internally mixed particles was mostly appropriate. As described earlier, for each period, the analysis focused on 5 sizes ranging from $117 \mathrm{~nm}$ to $160 \mathrm{~nm} . \kappa_{\text {org }}$ derived from these cases ranged from 0.04 to 0.11 with an average value of 0.08 , within the ranges observed in earlier studies (e.g., Hersey et al., 2011). These values are also in agreement with results from earlier smog chamber studies, which showed the hygroscopicity ranged from 0.04 to 0.14 for secondary organic aerosol formed from both biogenic and anthropogenic VOC precursors (Duplissy et al., 2008; Engelhart et al., 2008; Prenni et al., 2007; Wex et al., 2009).

\subsection{Relationship between $\kappa_{\text {org }}$ and organic oxidation level}

The relationship between derived $\kappa_{\text {org }}$ and $f_{44}$, which is the fraction of total organic mass signal at $m / z 44$, is shown in Fig. 4a. The $m / z 44$ signal is due mostly to acids (Duplissy et al., 2011; Takegawa et al., 2007) or acid-derived species, such as esters, and $f_{44}$ is closely related to the organic oxidation level (i.e., O : C ratio) (Aiken et al., 2008). The uncertainty of derived $\kappa_{\text {org }}$ was calculated using the approach described earlier. The precision of $f_{44}$ derived from measurements by the same AMS was estimated as $3 \%$ (relative variation; Aiken et al., 2008), and the inter-instrument variability for $f_{44}$ is about $10 \%$ (relative variation; $\mathrm{Ng}$ et al., 2010). As the results are compared to earlier studies during which $f_{44}$ was also derived from AMS measurements, the uncertainty in derived $f_{44}$ was estimated as $10 \%$ (Hayes et al., 2013). Also included in Fig. 4 are results based on similar analysis of the measurements carried out at the Los Angeles (LA) supersite during CalNex from 15 May to 4 June in 2010 (Mei et al., 2013). The LA supersite was principally a receptor site for pollution from downtown LA, and SOA was a major aerosol component at the site (Hayes et al., 2013). Overall, the dependences of $\kappa_{\text {org }}$ on $f_{44}$ are in agreement for organic aerosols observed at the CARES T1 and CalNex LA sites. Based on results from both sites, a least squares fit taking into consideration uncertainties in both derived $\kappa_{\mathrm{org}}$ and $f_{44}$ yielded $\kappa_{\text {org }}=2.10( \pm 0.07) \times f_{44}-0.11( \pm 0.01)$. The Pearson $R^{2}$ was 0.71 , suggesting most of the variation in $\kappa_{\text {org }}$ observed at the two sites can be explained by the variation in $f_{44}$ alone.

The variation of $\kappa_{\text {org }}$ was also examined as a function of organic oxidation level (i.e., $\mathrm{O}: \mathrm{C}$ atomic ratio) as was done in earlier studies, and the result is shown in Fig. 4b. For both sites, $\mathrm{O}: \mathrm{C}$ of size-selected $\mathrm{CCN}$ was calculated from sizeresolved $f_{44}$ using the specific relationship between $\mathrm{O}: \mathrm{C}$ and $f_{44}$, which was characterized using the bulk $\mathrm{O}: \mathrm{C}$ and $f_{44}$ derived from MS mode data collected at each site. This is an adaptation of the technique described by Aiken et al. (2008), which assumes that the relationship between $f_{44}$ and $\mathrm{O}: \mathrm{C}$ is independent of particle size. As discussed in Setyan et al. (2012), two distinct oxygenated organic aerosol (OOA) factors were identified during this study, including a more-oxidized OOA $\left(f_{44}=0.11 ; \mathrm{O}: \mathrm{C}=0.54\right)$ representative of biogenic SOA and a less-oxidized OOA $\left(f_{44}=0.13\right.$; $\mathrm{O}: \mathrm{C}=0.42$ ) representative of SOA formed in photochemically processed urban emissions. These two OOA factors together accounted for almost all of the variances observed in $\mathrm{O}: \mathrm{C}$ and $f_{44}$. As the two OOA factors exhibited similar size distributions (Setyan et al., 2012), they were likely internally mixed in particles during this study. Therefore, we expect the relationship between $f_{44}$ and $\mathrm{O}: \mathrm{C}$ was relatively independent of particle size.

The relationships were $\mathrm{O}: \mathrm{C}=3.99 \times f_{44}$ and $\mathrm{O}: \mathrm{C}=3.25 \times f_{44}$ for organic aerosols observed at the T1 site during CARES (i.e., this study) and the LA site during CalNex, respectively (Hayes et al., 2013; Setyan et al., 2012). The uncertainty in derived $\mathrm{O}: \mathrm{C}$ was similarly estimated as $10 \%$. Whereas overall $\kappa_{\text {org }}$ exhibited an increasing trend with increasing $\mathrm{O}: \mathrm{C}$, in agreement with earlier studies, the value of $\kappa_{\text {org }}$ derived from this study was statistically lower than that derived from data collected at the CalNex LA site when $\mathrm{O}: \mathrm{C}$ ranges from 0.35 to 0.45 . A 

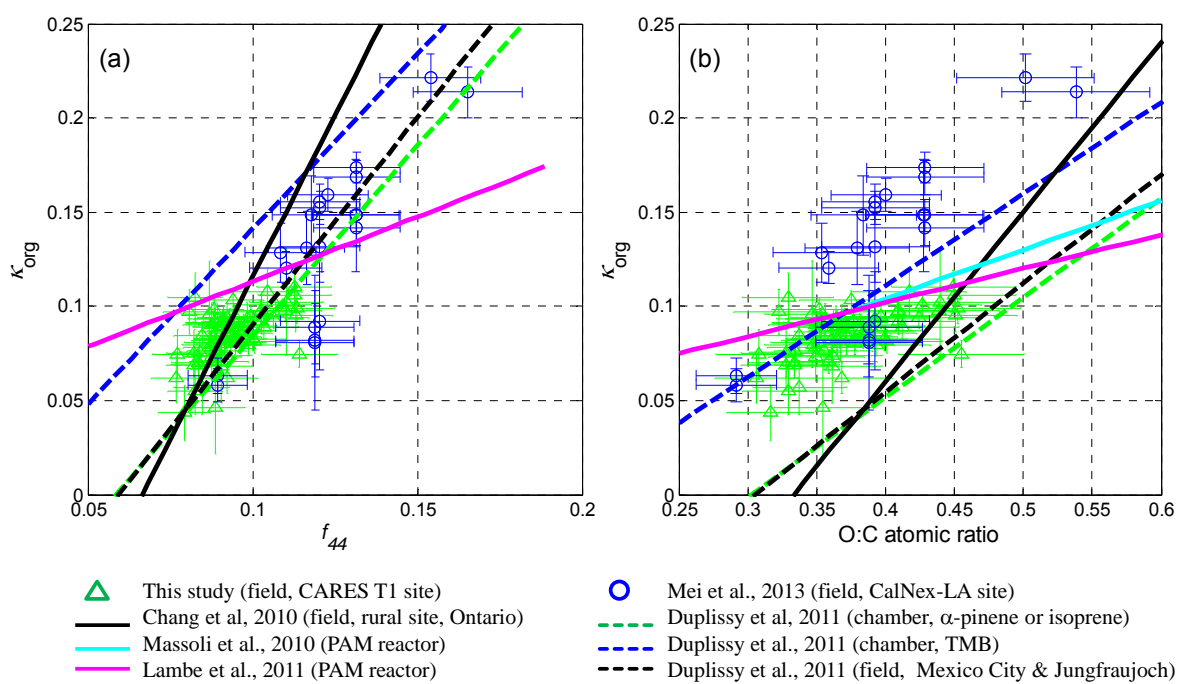

Fig. 5. Comparison with earlier studies on (a) the variation of $\kappa_{\mathrm{org}}$ with $f_{44}$ and (b) the variation of $\kappa_{\mathrm{org}}$ with $\mathrm{O}: \mathrm{C}$. The solid and dashed lines represent $\kappa_{\text {org }}$ derived under supersaturated and subsaturated conditions in earlier studies, respectively.

least squares fit of $\kappa_{\text {org }}$ vs. O : C yielded $\kappa_{\text {org }}=1.00( \pm 0.02)$ $\times(\mathrm{O}: \mathrm{C})-0.28( \pm 0.01)$ with a significantly lower $R^{2}$ value of 0.41 , suggesting that $\kappa_{\text {org }}$ may be better parameterized by $f_{44}$ than $\mathrm{O}: \mathrm{C}$.

The relationships between $\kappa_{\text {org }}$ and $f_{44}$ and between $\kappa_{\text {org }}$ and $\mathrm{O}: \mathrm{C}$ are compared to earlier studies described below (Fig. 5). Duplissy et al. (2011) reported $\kappa_{\text {org }}$ (under subsaturated conditions) derived from the GF of SOA formed from 1,3,5-trimethylbenzene (TMB), a surrogate for anthropogenic precursors, and SOA formed from representative biogenic precursors including isoprene and $\alpha$-pinene in a smog chamber. Also included in the comparison are the results derived from the GF of organic aerosols measured in Mexico City and at the high-alpine site Jungfraujoch, Switzerland (Duplissy et al., 2011). Chang et al. (2010) derived $\kappa_{\text {org }}$ based on CCN measurements at a rural site in Ontario, Canada. Using size-resolved CCN measurements, Massoli et al. (2010) and Lambe et al. (2011) examined the hygroscopicity of SOA and oxidized POA (OPOA) formed from the oxidation of a range of precursors representing atmospherically relevant biogenic and anthropogenic sources. The SOA and OPOA particles were generated via controlled exposure of precursors to $\mathrm{OH}$ radicals and/or $\mathrm{O}_{3}$ in a PAM flow reactor over timescales equivalent to 1-20 days of atmospheric aging resulting in $\mathrm{O}: \mathrm{C}$ ratios ranging from 0.05 to 1.42 .

The result from Massoli et al. (2010) was not included in Fig. 5a because $f_{44}$ values were not available. Overall, results from different studies showed quite consistent relationships between $\kappa_{\text {org }}$ and $f_{44}$. For example, the relationship derived from this study and the measurements at the CalNex LA site showed good agreement with those of ambient organic aerosols observed in Mexico City and at the high-alpine site
Jungfraujoch. At the same $f_{44}, \kappa_{\text {org }}$ of SOA formed from TMB in a smog chamber was substantially higher than those of SOA formed from isoprene and $\alpha$-pinene. One possible explanation is that for SOA formed from TMB photooxidation, the acids present in the aerosol are mainly mono-acids, while the acids found in the SOA from $\alpha$-pinene or isoprene photooxidation are approximately half mono- and half diacids (Duplissy et al., 2011). At a given $f_{44}$ value, $\kappa_{\text {org }}$ of ambient organic aerosol observed at the CARES T1 site, CalNex LA site, Mexico City, and Jungfraujoch was mostly between those of SOA formed from TMB and $\alpha$-pinene or isoprene in the smog chamber, possibly because ambient SOA was formed from both anthropogenic and biogenic precursors. Chang et al. (2010) reported similar $\kappa_{\text {org }}$ values at low $f_{44}$ around $0.08-0.10$, but a steeper increase of $\kappa_{\text {org }}$ with increasing $f_{44}$ than those observed in this study and at the CalNex LA site. Because $\kappa_{\text {org }}$ was derived from total CCN measurement (i.e., not size-resolved) in Chang et al. (2010), the relatively large uncertainty may partially explain some of the differences. For OA generated in PAM reactors, $\kappa_{\text {org }}$ overlapped with those derived from field measurements when $f_{44}$ ranges from 0.12 to 0.14 , but exhibited a substantially weaker dependence on $f_{44}$.

All studies show that $\kappa_{\text {org }}$ generally increases with increasing O:C. However, compared to the relationship between $\kappa_{\text {org }}$ and $f_{44}$, the relationship between $\kappa_{\text {org }}$ and $\mathrm{O}: \mathrm{C}$ exhibits more significant differences among the studies. For example, at $\mathrm{O}: \mathrm{C}$ ratio of $0.5, \kappa_{\text {org }}$ derived in above studies ranged from $\sim 0.1$ to $\sim 0.2$. For the results from Duplissy et al. (2011) and Chang et al. (2010), the differences may be partially due to the uncertainty in derived $\mathrm{O}: \mathrm{C}$ values. At present, AMS data analysis software only allows derivation of bulk $\mathrm{O}: \mathrm{C}$ through analysis of high-resolution mass spectral obtained 
during the MS mode operation. This approach was employed by Massoli et al. (2010) and Lambe et al. (2011) to derive the bulk $\mathrm{O}: \mathrm{C}$, which should represent $\mathrm{O}: \mathrm{C}$ at various $\mathrm{CCN}$ sizes in their studies, because no substantial $\mathrm{O}: \mathrm{C}$ dependence on particle size is expected for organic aerosols formed in the PAM reactor. For this study and Mei et al. (2013), organic $\mathrm{O}: \mathrm{C}$ at measured $\mathrm{CCN}$ sizes was derived from size-resolved $f_{44}$ using the relationship between $\mathrm{O}: \mathrm{C}$ and $f_{44}$, which was characterized using the bulk $\mathrm{O}: \mathrm{C}$ and $f_{44}$ derived from MS mode data collected at each site. This approach was also employed to derive $\mathrm{O}: \mathrm{C}$ from $f_{44}$ for some of the results presented in Lambe et al. (2011). Therefore, we expect that O : C values derived in this study, Lambe et al. (2011), and Mei et al. (2013) are reasonably accurate. Chang et al. (2010) and Duplissy et al. (2011) derived O:C using the relationship between $\mathrm{O}: \mathrm{C}$ and $f_{44}$ reported in an earlier study (Aiken et al., 2008), which might not be completely accurate for the aerosols observed in their studies.

Similar to the relationship between $\kappa_{\text {org }}$ and $f_{44}, \kappa_{\text {org }}$ of OA generated in a PAM reactor (Massoli et al., 2010; Lambe et al., 2011) exhibited a weaker dependence on $\mathrm{O}: \mathrm{C}$ than those derived from this study and Mei et al. (2013). At O : C values greater than $0.5, \kappa_{\text {org }}$ reported by Massoli et al. (2010) and Lambe et al. (2011) were substantially lower than those derived from field measurements (Mei et al., 2013). The organic mass loading examined by Massoli et al. (2010) ranged from 1 to $100 \mu \mathrm{g} \mathrm{m}^{-3}$, which encompasses the typical range of ambient OA mass loading. In addition, the relationship between $\kappa_{\text {org }}$ and O : C reported by Massoli et al. (2010) exhibited little dependence on organic mass loading. Therefore the differences in the relationship between $\kappa_{\text {org }}$ and O:C among the studies could not be explained by the variations in organic mass loading, and may be due to the differences in organic composition between ambient organic aerosols and those formed in PAM reactors. For example, the formation of SOA proceeded in the absence of $\mathrm{NO}_{\mathrm{x}}$ inside a PAM reactor in Massoli et al. (2010) and Lambe et al. (2011). However, ambient SOA may form under different $\mathrm{NO}_{\mathrm{x}}$ conditions, especially in the urban environment (e.g., at the CalNex LA site). In addition, the concentrations of oxidants inside a PAM reactor are several orders of magnitude higher than typically observed in the ambient atmosphere, which may potentially lead to different compounds in the SOA formed. Cloud processing and aqueous chemistry in wet aerosols may also contribute substantially to SOA formation, while SOA are mainly formed through gas phase reactions in a smog chamber or PAM reactor. This may also lead to different SOA composition and therefore the relationship between $\kappa_{\text {org }}$ and $\mathrm{O}: \mathrm{C}$. However, it is worth noting that the relationship between $\kappa_{\text {org }}$ and $f_{44}$ for SOA formed in a smog chamber (Duplissy et al., 2011) is quite consistent with that derived from some of the field studies (Fig. 5a). These discrepancies suggest that more results on $\kappa_{\text {org }}$ of ambient aerosols are needed to better understand and represent organic hygroscopicity in climate models, and future studies are needed to verify and understand the differences in $\kappa_{\text {org }}$ between ambient OA and those formed in PAM reactors shown in Fig. 5.

Organic aerosols exhibit a range of relationships between $f_{44}$ and $\mathrm{O}: \mathrm{C}$, as evidenced by the differences among the relationships observed at the T1 site, the CalNex LA site (Hayes et al., 2013), and those reported in previous studies (e.g., Aiken et al., 2008). The more consistent relationships between $\kappa_{\text {org }}$ and $f_{44}$ derived in different studies (Fig. 5a) and the higher $R^{2}$ value for the linear regression of $\kappa_{\text {org }}$ on $f_{44}$ (Fig. 4a) suggest that $\kappa_{\text {org }}$ may be better parameterized using $f_{44}$ than $\mathrm{O}: \mathrm{C}$. The stronger correlation between $\kappa_{\text {org }}$ and $f_{44}$ could be due to the following reasons. One key determinant of the hygroscopicity of organic compound is its water solubility. For typical ambient particles that are mixtures of both organic and inorganic species, organics with solubility less than $\sim 5 \times 10^{-4}$ have negligible contribution to CCN activation (i.e., negligible contribution to derived $\kappa_{\text {org }}$ ), whereas organics with solubility greater than $\sim 0.05$ are completely dissolved at the point of activation (Petters and Kreidenweis, 2008). Here the solubility is defined as the volume of solute per unit volume of water present in a saturated solution. The $\mathrm{CO}_{2}^{+}(\mathrm{m} / \mathrm{z} 44)$ is due mostly to acids (Duplissy et al., 2011) or acid-derived species, such as esters. Organic acids typically have higher solubility in water, and therefore may contribute significantly to the overall $\kappa_{\text {org }}$. Other oxygenated compounds in organic aerosol such as aldehydes may have much lower solubility, and therefore negligible contribution to the derived $\kappa_{\text {org }}$ if their solubility is less than $\sim 5 \times 10^{-4}$. This may explain the stronger correlation between $\kappa_{\text {org }}$ and $f_{44}$, as $f_{44}$ is closely related to the fraction of organic acids. It is worth noting that non-acid compounds such as methyl tetrols identified in SOA formed from isoprene also have high water solubility. However, these compounds may contribute to only a small fraction of the total organic aerosols, especially for those formed under high $\mathrm{NO}_{\mathrm{x}}$ condition (e.g., Edney et al., 2005). Currently, the identity and the solubility of many organic compounds in atmospheric aerosols are not known, and data on $\kappa_{\text {org }}$ for ambient aerosol are still quite limited. Future measurements are needed to verify the above findings, and to improve our understanding of $\kappa_{\mathrm{org}}$ and its relationship to composition.

\section{Conclusions}

During the CARES campaign, activation fraction of sizeresolved aerosol particles and aerosol chemical composition were characterized at the T1 site $(\sim 60 \mathrm{~km}$ downwind of Sacramento, California) from 10 June to 28 June 2010. Increases in aerosol mode diameter and organic mass loading were observed from 12:00 to 18:00, and are attributed to advection of secondary organic aerosols formed in the Sacramento urban plume through photochemical reactions. The hygroscopicity of $\mathrm{CCN}$-active particles with diameter from 100 to $170 \mathrm{~nm}$, derived from the size-resolved activated 
fraction, ranged from 0.10 to 0.20 , with an average of 0.15 , which is substantially lower than that proposed for continental sites (Andreae and Rosenfeld, 2008). The low $\kappa_{\mathrm{CCN}}$ value was due to the high organic volume fraction, averaged over $80 \%$ at the $\mathrm{T} 1$ site. The derived $\kappa_{\mathrm{CCN}}$ exhibited little diurnal variation, consistent with the relatively constant organic volume fraction observed. Unlikely earlier studies in the urban environment where $E$ decreased to $\sim 70 \%$ or lower during morning traffic hours, $E$ was always greater than $\sim 90 \%$ for particles with diameter between 100 and $171 \mathrm{~nm}$, suggesting the vast majority particles within this size range were aged background particles. The average hygroscopicity dispersion of size-selected CCN was 0.29 , substantially lower than those observed in the urban environment ( $\mathrm{Su}$ et al., 2010; Padro et al., 2012; Mei et al., 2013), also reflecting more aged aerosols observed at the T1 site. These observations are in agreement with previous studies that show that hydrophobic particles emitted in urban areas quickly become internal mixtures and hydrophilic by condensation of secondary hygroscopic species, such as SOA (Riemer et al., 2004, 2009; Moffet and Prather, 2009; Wang et al., 2010; Mei et al., 2013), and aerosol composition becomes increasingly more homogeneous as particles age through coagulation and condensation of secondary species (Mei et al., 2013; Wang et al., 2010).

The sensitivity of calculated $N_{\mathrm{CCN}}$ to $\kappa_{\text {org }}$ was examined for aerosol observed at the T1 site. The sensitivity increased with increasing organic volume fraction, in agreement with earlier studies (e.g., Chang et al., 2007; Wang et al., 2008). Due to the large organic volume fraction, $\kappa_{\text {org }}$ strongly impacted calculated $N_{\mathrm{CCN}}$. For the vast majority of the cases, an increase of $\kappa_{\text {org }}$ from 0.03 to 0.18 , which are within the type range, doubled the calculated $N_{\mathrm{CCN}}$. Even a minor increase of $\kappa_{\text {org }}$ from 0.08 to 0.13 led to a $30 \%$ increase of the calculated $N_{\mathrm{CCN}}$. Future stricter control of sulfur emission will likely lead to increased aerosol organic volume fraction and therefore stronger dependence of simulated $N_{\mathrm{CCN}}$ to $\kappa_{\text {org }}$ when projecting future climate change.

Organic hygroscopicity was derived from $\kappa_{\mathrm{CCN}}$ and aerosol chemical composition, and its variations with $f_{44}$ and $\mathrm{O}: \mathrm{C}$ were compared to results from previous studies. Overall, the relationships between $\kappa_{\text {org }}$ and $f_{44}$ are quite consistent for ambient OA and those formed in a smog chamber. However, $\kappa_{\text {org }}$ of OA formed in PAM reactors exhibited weaker dependence on $f_{44}$ or $\mathrm{O}: \mathrm{C}$ when compared to those of ambient OA. The discrepancy may be due to the differences in organic compositions. Compared to the relationship between $\kappa_{\text {org }}$ and $f_{44}$, the relationship between $\kappa_{\text {org }}$ and $\mathrm{O}: \mathrm{C}$ exhibits more significant differences among different studies. While some of the differences may be due to the uncertainty in derived $\mathrm{O}: \mathrm{C}$ values, the comparison suggests $\kappa_{\text {org }}$ may be better parameterized using $f_{44}$. A least squares fit of $\kappa_{\text {org }}$ on $f_{44}$ yielded $\kappa_{\text {org }}=2.04( \pm 0.07) \times f_{44}-0.11( \pm 0.01)$ with a Pearson $R^{2}$ value of 0.71 . One possible explanation for the stronger correlation between $\kappa_{\text {org }}$ and $f_{44}$ is that the signal at $m / z 44$ is closely related to organic acids, which may dominate the overall $\kappa_{\text {org }}$ due to its relatively high water solubility and hygroscopicity. Future measurements of $\kappa_{\text {org }}$ of ambient aerosols are needed to verify these findings, and to better understand $\kappa_{\text {org }}$ and its relationship to the composition for their representations in climate models.

\section{Supplementary material related to this article is available online at http://www.atmos-chem-phys.net/13/ 12155/2013/acp-13-12155-2013-supplement.pdf.}

Acknowledgements. This research was performed with support from the US Department of Energy Atmospheric System Research program under contract number DE-AC02-98CH10866 and DE-FG02-11ER65293. We acknowledge the US Department of Energy Atmospheric Radiation Measurement program and Pacific Northwest National Laboratory for logistics support.

Edited by: J. Thornton

\section{References}

Abbatt, J. P. D., Broekhuizen, K., and Kumal, P. P.: Cloud condensation nucleus activity of internally mixed ammonium sulfate/organic acid aerosol particles, Atmos. Environ., 39, 47674778, 2005.

Aiken, A. C., Decarlo, P. F., Kroll, J. H., Worsnop, D. R., Huffman, J. A., Docherty, K. S., Ulbrich, I. M., Mohr, C., Kimmel, J. R., Sueper, D., Sun, Y., Zhang, Q., Trimborn, A., Northway, M., Ziemann, P. J., Canagaratna, M. R., Onasch, T. B., Alfarra, M. R., Prevot, A. S. H., Dommen, J., Duplissy, J., Metzger, A., Baltensperger, U., and Jimenez, J. L.: O/C and OM/OC ratios of primary, secondary, and ambient organic aerosols with high-resolution time-of-flight aerosol mass spectrometry, Environ. Sci. Technol., 42, 4478-4485, 2008.

Albrecht, B. A.: Aerosols, cloud microphysics, and fractional cloudiness, Science, 245, 1227-1230, 1989.

Andreae, M. O. and Rosenfeld, D.: Aerosol-cloud-precipitation interactions. Part 1. The nature and sources of cloud-active aerosols, Earth Sci. Rev., 89, 13-41, 2008.

Asa-Awuku, A., Engelhart, G. J., Lee, B. H., Pandis, S. N., and Nenes, A.: Relating CCN activity, volatility, and droplet growth kinetics of $\beta$-caryophyllene secondary organic aerosol, Atmos. Chem. Phys., 9, 795-812, doi:10.5194/acp-9-795-2009, 2009.

Bilde, M. and Svenningsson, B.: CCN activation of slightly soluble organics: the importance of small amounts of inorganic salt and particle phase, Tellus B, 56, 128-134, 2004.

Bougiatioti, A., Nenes, A., Fountoukis, C., Kalivitis, N., Pandis, S. N., and Mihalopoulos, N.: Size-resolved CCN distributions and activation kinetics of aged continental and marine aerosol, Atmos. Chem. Phys., 11, 8791-8808, doi:10.5194/acp-11-87912011, 2011.

Cerully, K. M., Raatikainen, T., Lance, S., Tkacik, D., Tiitta, P., Petäjä, T., Ehn, M., Kulmala, M., Worsnop, D. R., Laaksonen, 
A., Smith, J. N., and Nenes, A.: Aerosol hygroscopicity and CCN activation kinetics in a boreal forest environment during the 2007 EUCAARI campaign, Atmos. Chem. Phys., 11, 12369-12386, doi:10.5194/acp-11-12369-2011, 2011.

Chang, R. Y. W., Liu, P. S. K., Leaitch, W. R., and Abbatt, J. P. D.: Comparison between measured and predicted $\mathrm{CCN}$ concentrations at Egbert, Ontario: Focus on the organic aerosol fraction at a semi-rural site, Atmos. Environ., 41, 8172-8182, 2007.

Chang, R. Y.-W., Slowik, J. G., Shantz, N. C., Vlasenko, A., Liggio, J., Sjostedt, S. J., Leaitch, W. R., and Abbatt, J. P. D.: The hygroscopicity parameter $(\kappa)$ of ambient organic aerosol at a field site subject to biogenic and anthropogenic influences: relationship to degree of aerosol oxidation, Atmos. Chem. Phys., 10, 5047-5064, doi:10.5194/acp-10-5047-2010, 2010.

Collins, D. R., Flagan, R. C., and Seinfeld, J. H.: Improved inversion of scanning DMA data, Aerosol Sci. Technol., 36, 1-9, 2002.

DeCarlo, P. F., Kimmel, J. R., Trimborn, A., Northway, M. J., Jayne, J. T., Aiken, A. C., Gonin, M., Fuhrer, K., Horvath, T., Docherty, K., Worsnop, D. R., and Jimenez, J. L.: Field-Deployable, HighResolution, Time-of-Flight Aerosol Mass Spectrometer, Anal. Chem., 78, 8281-8289, 2006.

Duplissy, J., Gysel, M., Alfarra, M. R., Dommen, J., Metzger, A., Prevot, A. S. H., Weingartner, E., Laaksonen, A., Raatikainen, T., Good, N., Turner, S. F., McFiggans, G., and Baltensperger, U.: Cloud forming potential of secondary organic aerosol under near atmospheric conditions, Geophys. Res. Lett., 35, L03818, doi:10.1029/2007GL031075, 2008.

Duplissy, J., DeCarlo, P. F., Dommen, J., Alfarra, M. R., Metzger, A., Barmpadimos, I., Prevot, A. S. H., Weingartner, E., Tritscher, T., Gysel, M., Aiken, A. C., Jimenez, J. L., Canagaratna, M. R., Worsnop, D. R., Collins, D. R., Tomlinson, J., and Baltensperger, U.: Relating hygroscopicity and composition of organic aerosol particulate matter, Atmos. Chem. Phys., 11, 11551165, doi:10.5194/acp-11-1155-2011, 2011.

Edney, E. O., Kleindienst, T. E., Jaoui, M., Lewandowski, M., Offenberg, J. H., Wang, W., and Claeys, M.: Formation of 2-methyl tetrols and 2-methylglyceric acid in secondary organic aerosol from laboratory irradiated isoprene/ $\mathrm{NO}(\mathrm{X}) / \mathrm{SO}(2) /$ air mixtures and their detection in ambient $\operatorname{PM}(2.5)$ samples collected in the eastern United States, Atmos. Environ., 39, 5281-5289, doi:10.1016/j.atmosenv.2005.05.031, 2005.

Engelhart, G. J., Asa-Awuku, A., Nenes, A., and Pandis, S. N.: CCN activity and droplet growth kinetics of fresh and aged monoterpene secondary organic aerosol, Atmos. Chem. Phys., 8, 39373949, doi:10.5194/acp-8-3937-2008, 2008.

Ervens, B., Cubison, M. J., Andrews, E., Feingold, G., Ogren, J. A., Jimenez, J. L., Quinn, P. K., Bates, T. S., Wang, J., Zhang, Q., Coe, H., Flynn, M., and Allan, J. D.: CCN predictions using simplified assumptions of organic aerosol composition and mixing state: a synthesis from six different locations, Atmos. Chem. Phys., 10, 4795-4807, doi:10.5194/acp-10-4795-2010, 2010.

Good, N., Topping, D. O., Allan, J. D., Flynn, M., Fuentes, E., Irwin, M., Williams, P. I., Coe, H., and McFiggans, G.: Consistency between parameterisations of aerosol hygroscopicity and CCN activity during the RHaMBLe discovery cruise, Atmos. Chem. Phys., 10, 3189-3203, doi:10.5194/acp-10-3189-2010, 2010.

Gunthe, S. S., King, S. M., Rose, D., Chen, Q., Roldin, P., Farmer, D. K., Jimenez, J. L., Artaxo, P., Andreae, M. O., Martin, S.
T., and Pöschl, U.: Cloud condensation nuclei in pristine tropical rainforest air of Amazonia: size-resolved measurements and modeling of atmospheric aerosol composition and CCN activity, Atmos. Chem. Phys., 9, 7551-7575, doi:10.5194/acp-9-75512009, 2009.

Hayes, P. L., Ortega, A. M., Cubison, M. J., Froyd, K. D., Zhao, Y., Cliff, S. S., Hu, W. W., Toohey, D. W., Flynn, J. H., Lefer, B. L., Grossberg, N., Alvarez, S., Rappenglück, B., Taylor, J. W., Allan, J. D., Holloway, J. S., Gilman, J. B., Kuster, W. C., Gouw, J. A. d., Massoli, P., Zhang, X., Liu, J., Weber, R. J., Corrigan, A. L., Russell, L. M., Isaacman, G., Worton, D. R., Kreisberg, N. M., Hering, S. V., Goldstein, A. H., Thalman, R., Waxman, E. M., Volkamer, R., Lin, Y. H., Surratt, J. D., Kleindienst, T. E., Offenberg, J. H., Dusanter, S., Griffith, S., Stevens, P. S., Brioude, J., Angevine, W. M., and Jimenez, J. L.: Aerosol Composition and Sources in Los Angeles during the 2010 CalNex Campaign, J. Geophys. Res., 118, 9233-9257, doi:10.1002/jgrd.50530, 2013.

Hersey, S. P., Craven, J. S., Schilling, K. A., Metcalf, A. R., Sorooshian, A., Chan, M. N., Flagan, R. C., and Seinfeld, J. H.: The Pasadena Aerosol Characterization Observatory (PACO): chemical and physical analysis of the Western Los Angeles basin aerosol, Atmos. Chem. Phys., 11, 7417-7443, doi:10.5194/acp11-7417-2011, 2011.

Hudson, J. G. and Da, X. Y.: Volatility and size of cloud condensation nuclei, J. Geophys. Res., 101, 4435-4442, 1996.

Huff-Hartz, K. E. H., Tischuk, J. E., Chan, M. N., Chan, C. K., Donahue, N. M., and Pandis, S. N.: Cloud condensation nuclei activation of limited solubility organic aerosol, Atmos. Environ., 40, 605-617, 2006.

IPCC: Climate Change 2007 - The Physical Science Basis: Contribution of Working Group I to the Fourth Assessment Report of the IPCC, Cambridge University Press, New York, 2007.

Jimenez, J. L., Canagaratna, M. R., Donahue, N. M., Prevot, A. S. H., Zhang, Q., Kroll, J. H., DeCarlo, P. F., Allan, J. D., Coe, H., Ng, N. L., Aiken, A. C., Docherty, K. S., Ulbrich, I. M., Grieshop, A. P., Robinson, A. L., Duplissy, J., Smith, J. D., Wilson, K. R., Lanz, V. A., Hueglin, C., Sun, Y. L., Tian, J., Laaksonen, A., Raatikainen, T., Rautiainen, J., Vaattovaara, P., Ehn, M., Kulmala, M., Tomlinson, J. M., Collins, D. R., Cubison, M. J., Dunlea, E. J., Huffman, J. A., Onasch, T. B., Alfarra, M. R., Williams, P. I., Bower, K., Kondo, Y., Schneider, J., Drewnick, F., Borrmann, S., Weimer, S., Demerjian, K., Salcedo, D., Cottrell, L., Griffin, R., Takami, A., Miyoshi, T., Hatakeyama, S., Shimono, A., Sun, J. Y., Zhang, Y. M., Dzepina, K., Kimmel, J. R., Sueper, D., Jayne, J. T., Herndon, S. C., Trimborn, A. M., Williams, L. R., Wood, E. C., Middlebrook, A. M., Kolb, C. E., Baltensperger, U., and Worsnop, D. R.: Evolution of Organic Aerosols in the Atmosphere, Science, 326, 1525-1529, 2009.

Kammermann, L., Gysel, M., Weingartner, E., Herich, H., Cziczo, D. J., Holst, T., Svenningsson, B., Arneth, A., and Baltensperger, U.: Subarctic atmospheric aerosol composition: 3. Measured and modeled properties of cloud condensation nuclei, J. Geophys. Res., 115, D04202, doi:10.1029/2009JD012447, 2010.

Kanakidou, M., Seinfeld, J. H., Pandis, S. N., Barnes, I., Dentener, F. J., Facchini, M. C., Van Dingenen, R., Ervens, B., Nenes, A., Nielsen, C. J., Swietlicki, E., Putaud, J. P., Balkanski, Y., Fuzzi, S., Horth, J., Moortgat, G. K., Winterhalter, R., Myhre, C. E. L., Tsigaridis, K., Vignati, E., Stephanou, E. G., and Wilson, J.: Organic aerosol and global climate modelling: a review, 
Atmos. Chem. Phys., 5, 1053-1123, doi:10.5194/acp-5-10532005, 2005.

King, S. M., Rosenoern, T., Shilling, J. E., Chen, Q., and Martin, S. T.: Increased cloud activation potential of secondary organic aerosol for atmospheric mass loadings, Atmos. Chem. Phys., 9, 2959-2971, doi:10.5194/acp-9-2959-2009, 2009.

Köhler, H.: The nucleus in and the growth of hygroscopic droplets, Trans. Farad. Soc., 32, 1152-1161, 1936.

Kuwata, M., Zorn, S. R., and Martin, S. T.: Using Elemental Ratios to Predict the Density of Organic Material Composed of Carbon, Hydrogen, and Oxygen, Environ. Sci. Technol., 46, 787794, 2012.

Lambe, A. T., Onasch, T. B., Massoli, P., Croasdale, D. R., Wright, J. P., Ahern, A. T., Williams, L. R., Worsnop, D. R., Brune, W. H., and Davidovits, P.: Laboratory studies of the chemical composition and cloud condensation nuclei $(\mathrm{CCN})$ activity of secondary organic aerosol (SOA) and oxidized primary organic aerosol (OPOA), Atmos. Chem. Phys., 11, 8913-8928, doi:10.5194/acp11-8913-2011, 2011.

Lance, S.: Quantifying compositional impacts of ambient aerosol on cloud droplet formation, Ph.D., Georgia Institute of Technology, Atlanta, 2007.

Lance, S., Medina, J., Smith, J. N., and Nenes, A.: Mapping the operation of the DMT Continuous Flow CCN counter, Aerosol Sci. Technol., 40, 242-254, 2006.

Lance, S., Raatikainen, T., Onasch, T. B., Worsnop, D. R., Yu, X.-Y., Alexander, M. L., Stolzenburg, M. R., McMurry, P. H., Smith, J. N., and Nenes, A.: Aerosol mixing state, hygroscopic growth and cloud activation efficiency during MIRAGE 2006, Atmos. Chem. Phys., 13, 5049-5062, doi:10.5194/acp-13-5049-2013, 2013.

Lathem, T. L., Beyersdorf, A. J., Thornhill, K. L., Winstead, E. L., Cubison, M. J., Hecobian, A., Jimenez, J. L., Weber, R. J., Anderson, B. E., and Nenes, A.: Analysis of CCN activity of Arctic aerosol and Canadian biomass burning during summer 2008, Atmos. Chem. Phys., 13, 2735-2756, doi:10.5194/acp-13-27352013, 2013.

Liu, X. and Wang, J.: How important is organic aerosol hygroscopicity to aerosol indirect forcing?, Environ. Res. Lett., 5, 044010 , doi:10.1088/1748-9326/5/4/044010, 2010.

Massoli, P., Lambe, A. T., Ahern, A. T., Williams, L. R., Ehn, M., Mikkila, J., Canagaratna, M. R., Brune, W. H., Onasch, T. B., Jayne, J. T., Petaja, T., Kulmala, M., Laaksonen, A., Kolb, C. E., Davidovits, P., and Worsnop, D. R.: Relationship between aerosol oxidation level and hygroscopic properties of laboratory generated secondary organic aerosol (SOA) particles, Geophys. Res. Lett., 37, L24801, doi:10.1029/2010GL045258, 2010.

McFiggans, G., Artaxo, P., Baltensperger, U., Coe, H., Facchini, M. C., Feingold, G., Fuzzi, S., Gysel, M., Laaksonen, A., Lohmann, U., Mentel, T. F., Murphy, D. M., O'Dowd, C. D., Snider, J. R., and Weingartner, E.: The effect of physical and chemical aerosol properties on warm cloud droplet activation, Atmos. Chem. Phys., 6, 2593-2649, doi:10.5194/acp-6-2593-2006, 2006.

Mei, F., Hayes, P. L., Ortega, A. M., Taylor, J. W., Allan, J. D., Gilman, J. B., Kuster, W. C., de Gouw, J. A., Jimenez, J. L., and Wang, J.: Droplet activation properties of organic aerosols observed at an urban site during CalNex-LA, J. Geophys. Res., 118, 2903-2917, doi:10.1002/jgrd.50285, 2013.

Moffet, R. C. and Prather, K. A.: In-situ measurements of the mixing state and optical properties of soot with implications for ra- diative forcing estimates, P. Natl. Acad. Sci. USA, 106, 1187211877, 2009.

Moore, R. H., Bahreini, R., Brock, C. A., Froyd, K. D., Cozic, J., Holloway, J. S., Middlebrook, A. M., Murphy, D. M., and Nenes, A.: Hygroscopicity and composition of Alaskan Arctic CCN during April 2008, Atmos. Chem. Phys., 11, 11807-11825, doi:10.5194/acp-11-11807-2011, 2011.

Moore, R. H., Cerully, K., Bahreini, R., Brock, C. A., Middlebrook, A. M., and Nenes, A.: Hygroscopicity and composition of California CCN during summer 2010, J. Geophys. Res., 117, D00V12, doi:10.1029/2011JD017352, 2012.

Ng, N. L., Canagaratna, M. R., Zhang, Q., Jimenez, J. L., Tian, J., Ulbrich, I. M., Kroll, J. H., Docherty, K. S., Chhabra, P. S., Bahreini, R., Murphy, S. M., Seinfeld, J. H., Hildebrandt, L., Donahue, N. M., DeCarlo, P. F., Lanz, V. A., Prévôt, A. S. H., Dinar, E., Rudich, Y., and Worsnop, D. R.: Organic aerosol components observed in Northern Hemispheric datasets from Aerosol Mass Spectrometry, Atmos. Chem. Phys., 10, 46254641, doi:10.5194/acp-10-4625-2010, 2010.

Padró, L. T., Moore, R. H., Zhang, X., Rastogi, N., Weber, R. J., and Nenes, A.: Mixing state and compositional effects on CCN activity and droplet growth kinetics of size-resolved $\mathrm{CCN}$ in an urban environment, Atmos. Chem. Phys., 12, 10239-10255, doi:10.5194/acp-12-10239-2012, 2012.

Petters, M. D. and Kreidenweis, S. M.: A single parameter representation of hygroscopic growth and cloud condensation nucleus activity, Atmos. Chem. Phys., 7, 1961-1971, doi:10.5194/acp-71961-2007, 2007.

Petters, M. D. and Kreidenweis, S. M.: A single parameter representation of hygroscopic growth and cloud condensation nucleus activity - Part 2: Including solubility, Atmos. Chem. Phys., 8, 6273-6279, doi:10.5194/acp-8-6273-2008, 2008.

Petters, M. D., Carrico, C. M., Kreidenweis, S. M., Prenni, A. J., DeMott, P. J., Collett, J. L., and Moosmuller, H.: Cloud condensation nucleation activity of biomass burning aerosol, J. Geophys. Res., 114, D22205, doi:10.1029/2009JD012353, 2009a.

Petters, M. D., Wex, H., Carrico, C. M., Hallbauer, E., Massling, A., McMeeking, G. R., Poulain, L., Wu, Z., Kreidenweis, S. M., and Stratmann, F.: Towards closing the gap between hygroscopic growth and activation for secondary organic aerosol - Part 2: Theoretical approaches, Atmos. Chem. Phys., 9, 3999-4009, doi:10.5194/acp-9-3999-2009, 2009b.

Pradeep Kumar, P., Broekhuizen, K., and Abbatt, J. P. D.: Organic acids as cloud condensation nuclei: Laboratory studies of highly soluble and insoluble species, Atmos. Chem. Phys., 3, 509-520, doi:10.5194/acp-3-509-2003, 2003.

Prenni, A. J., Petters, M. D., Kreidenweis, S. M., DeMott, P. J., and Ziemann, P. J.: Cloud droplet activation of secondary organic aerosol, J. Geophys. Res., 112, D10223, doi:10.1029/2006JD007963, 2007.

Raymond, T. M. and Pandis, S. N.: Cloud activation of singlecomponent organic aerosol particles, J. Geophys. Res., 107, 4787, doi:10.1029/2002JD002159, 2002.

Raymond, T. M. and Pandis, S. N.: Formation of cloud droplets by multicomponent organic particles, J. Geophys. Res., 108, 4469, doi:10.1029/2003JD003503, 2003.

Reutter, P., Su, H., Trentmann, J., Simmel, M., Rose, D., Gunthe, S. S., Wernli, H., Andreae, M. O., and Pöschl, U.: Aerosol- and updraft-limited regimes of cloud droplet formation: influence of 
particle number, size and hygroscopicity on the activation of cloud condensation nuclei (CCN), Atmos. Chem. Phys., 9, 70677080, doi:10.5194/acp-9-7067-2009, 2009.

Riemer, N., Vogel, H., and Vogel, B.: Soot aging time scales in polluted regions during day and night, Atmos. Chem. Phys., 4, 1885-1893, doi:10.5194/acp-4-1885-2004, 2004.

Riemer, N., West, M., Zaveri, R. A., and Easter, R. C.: Simulating the evolution of soot mixing state with a particleresolved aerosol model, J. Geophys. Res., 114, D09202 doi:10.1029/2008JD011073, 2009.

Rissler, J., Vestin, A., Swietlicki, E., Fisch, G., Zhou, J., Artaxo, P., and Andreae, M. O.: Size distribution and hygroscopic properties of aerosol particles from dry-season biomass burning in Amazonia, Atmos. Chem. Phys., 6, 471-491, doi:10.5194/acp6-471-2006, 2006.

Rissman, T. A., Nenes, A., and Seinfeld, J. H.: Chemical amplification (or dampening) of the Twomey effect: Conditions derived from droplet activation theory, J. Atmos. Sci., 61, 919-930, 2004.

Roberts, G. C. and Nenes, A.: A continuous-flow streamwise thermal-gradient $\mathrm{CCN}$ chamber for atmospheric measurements, Aerosol Sci. Technol., 39, 206-221, 2005.

Rose, D., Gunthe, S. S., Mikhailov, E., Frank, G. P., Dusek, U., Andreae, M. O., and Pöschl, U.: Calibration and measurement uncertainties of a continuous-flow cloud condensation nuclei counter (DMT-CCNC): CCN activation of ammonium sulfate and sodium chloride aerosol particles in theory and experiment, Atmos. Chem. Phys., 8, 1153-1179, doi:10.5194/acp-8-11532008, 2008.

Rose, D., Nowak, A., Achtert, P., Wiedensohler, A., Hu, M., Shao, M., Zhang, Y., Andreae, M. O., and Pöschl, U.: Cloud condensation nuclei in polluted air and biomass burning smoke near the mega-city Guangzhou, China - Part 1: Size-resolved measurements and implications for the modeling of aerosol particle hygroscopicity and CCN activity, Atmos. Chem. Phys., 10, 33653383, doi:10.5194/acp-10-3365-2010, 2010.

Setyan, A., Zhang, Q., Merkel, M., Knighton, W. B., Sun, Y., Song, C., Shilling, J. E., Onasch, T. B., Herndon, S. C., Worsnop, D. R., Fast, J. D., Zaveri, R. A., Berg, L. K., Wiedensohler, A., Flowers, B. A., Dubey, M. K., and Subramanian, R.: Characterization of submicron particles influenced by mixed biogenic and anthropogenic emissions using high-resolution aerosol mass spectrometry: results from CARES, Atmos. Chem. Phys., 12, 8131-8156, doi:10.5194/acp-12-8131-2012, 2012.

Shantz, N. C., Leaitch, W. R., Phinney, L., Mozurkewich, M., and Toom-Sauntry, D.: The effect of organic compounds on the growth rate of cloud droplets in marine and forest settings, Atmos. Chem. Phys., 8, 5869-5887, doi:10.5194/acp-8-5869-2008, 2008.

Su, H., Rose, D., Cheng, Y. F., Gunthe, S. S., Massling, A., Stock, M., Wiedensohler, A., Andreae, M. O., and Pöschl, U.: Hygroscopicity distribution concept for measurement data analysis and modeling of aerosol particle mixing state with regard to hygroscopic growth and CCN activation, Atmos. Chem. Phys., 10, 7489-7503, doi:10.5194/acp-10-7489-2010, 2010.

Svenningsson, B., Rissler, J., Swietlicki, E., Mircea, M., Bilde, M., Facchini, M. C., Decesari, S., Fuzzi, S., Zhou, J., Mønster, J., and Rosenørn, T.: Hygroscopic growth and critical supersaturations for mixed aerosol particles of inorganic and organic compounds of atmospheric relevance, Atmos. Chem. Phys., 6, 1937-1952, doi:10.5194/acp-6-1937-2006, 2006.

Takegawa, N., Miyakawa, T., Kawamura, K., and Kondo, Y.: Contribution of selected dicarboxylic and omega-oxocarboxylic acids in ambient aerosol to the $\mathrm{m} / \mathrm{z}, 44$ signal of an aerodyne aerosol mass spectrometer, Aerosol Sci. Technol., 41, 418-437, doi:10.1080/02786820701203215, 2007.

ToF-AMS Analysis Software: http://cires.colorado.edu/ jimenez-group/wiki/index.php/ToF-AMS_Analysis_Software, 2011.

Twomey, S.: Influence of Pollution on Shortwave Albedo of Clouds, J. Atmos. Sci., 34, 1149-1152, 1977.

Wang, J.: Effects of spatial and temporal variations in aerosol properties on mean cloud albedo, J. Geophys. Res., 112, D16201, doi:10.1029/2007JD008565, 2007.

Wang, J., Flagan, R. C., and Seinfeld, J. H.: A differential mobility analyzer (DMA) system for submicron aerosol measurements at ambient relative humidity, Aerosol Sci. Technol., 37, 46-52, 2003.

Wang, J., Lee, Y.-N., Daum, P. H., Jayne, J., and Alexander, M. L.: Effects of aerosol organics on cloud condensation nucleus (CCN) concentration and first indirect aerosol effect, Atmos. Chem. Phys., 8, 6325-6339, doi:10.5194/acp-8-6325-2008, 2008.

Wang, J., Cubison, M. J., Aiken, A. C., Jimenez, J. L., and Collins, D. R.: The importance of aerosol mixing state and size-resolved composition on $\mathrm{CCN}$ concentration and the variation of the importance with atmospheric aging of aerosols, Atmos. Chem. Phys., 10, 7267-7283, doi:10.5194/acp-10-7267-2010, 2010.

Wang, S. C. and Flagan, R. C.: Scanning Electrical Mobility Spectrometer, Aerosol Sci. Technol., 13, 230-240, 1990.

Ward, D. S., Eidhammer, T., Cotton, W. R., and Kreidenweis, S. M.: The role of the particle size distribution in assessing aerosol composition effects on simulated droplet activation, Atmos. Chem. Phys., 10, 5435-5447, doi:10.5194/acp-10-5435-2010, 2010.

Wex, H., Hennig, T., Salma, I., Ocskay, R., Kiselev, A., Henning, S., Massling, A., Wiedensohler, A., and Stratmann, F.: Hygroscopic growth and measured and modeled critical super-saturations of an atmospheric HULIS sample, Geophys. Res. Lett., 34, L02818, doi:10.1029/2006GL028260, 2007.

Wex, H., Stratmann, F., Topping, D., and McFiggans, G.: The Kelvin versus the Raoult Term in the Kohler Equation, J. Atmos. Sci., 65, 4004-4016, 2008.

Wex, H., Petters, M. D., Carrico, C. M., Hallbauer, E., Massling, A., McMeeking, G. R., Poulain, L., Wu, Z., Kreidenweis, S. M., and Stratmann, F.: Towards closing the gap between hygroscopic growth and activation for secondary organic aerosol: Part 1 - Evidence from measurements, Atmos. Chem. Phys., 9, 3987-3997, doi:10.5194/acp-9-3987-2009, 2009.

Zaveri, R. A., Shaw, W. J., Cziczo, D. J., Schmid, B., Ferrare, R. A., Alexander, M. L., Alexandrov, M., Alvarez, R. J., Arnott, W. P., Atkinson, D. B., Baidar, S., Banta, R. M., Barnard, J. C., Beranek, J., Berg, L. K., Brechtel, F., Brewer, W. A., Cahill, J. F., Cairns, B., Cappa, C. D., Chand, D., China, S., Comstock, J. M., Dubey, M. K., Easter, R. C., Erickson, M. H., Fast, J. D., Floerchinger, C., Flowers, B. A., Fortner, E., Gaffney, J. S., Gilles, M. K., Gorkowski, K., Gustafson, W. I., Gyawali, M., Hair, J., Hardesty, R. M., Harworth, J. W., Herndon, S., Hiranuma, N., Hostetler, C., Hubbe, J. M., Jayne, J. T., Jeong, H., Jobson, B. T., Kassianov, E. I., Kleinman, L. I., Kluzek, C., 
Knighton, B., Kolesar, K. R., Kuang, C., Kubátová, A., Langford, A. O., Laskin, A., Laulainen, N., Marchbanks, R. D., Mazzoleni, C., Mei, F., Moffet, R. C., Nelson, D., Obland, M. D., Oetjen, H., Onasch, T. B., Ortega, I., Ottaviani, M., Pekour, M., Prather, K. A., Radney, J. G., Rogers, R. R., Sandberg, S. P., Sedlacek, A., Senff, C. J., Senum, G., Setyan, A., Shilling, J. E., Shrivastava, M., Song, C., Springston, S. R., Subramanian, R., Suski, K., Tomlinson, J., Volkamer, R., Wallace, H. W., Wang, J., Weickmann, A. M., Worsnop, D. R., Yu, X.-Y., Zelenyuk, A., and Zhang, Q.: Overview of the 2010 Carbonaceous Aerosols and Radiative Effects Study (CARES), Atmos. Chem. Phys., 12, 7647-7687, doi:10.5194/acp-12-7647-2012, 2012.
Zhang, Q., Jimenez, J. L., Canagaratna, M. R., Allan, J. D., Coe, H., Ulbrich, I., Alfarra, M. R., Takami, A., Middlebrook, A. M., Sun, Y. L., Dzepina, K., Dunlea, E., Docherty, K., DeCarlo, P. F., Salcedo, D., Onasch, T., Jayne, J. T., Miyoshi, T., Shimono, A., Hatakeyama, S., Takegawa, N., Kondo, Y., Schneider, J., Drewnick, F., Borrmann, S., Weimer, S., Demerjian, K., Williams, P., Bower, K., Bahreini, R., Cottrell, L., Griffin, R. J., Rautiainen, J., Sun, J. Y., Zhang, Y. M., and Worsnop, D. R.: Ubiquity and dominance of oxygenated species in organic aerosols in anthropogenically-influenced Northern Hemisphere midlatitudes, Geophys. Res. Lett., 34, L13801, doi:10.1029/2007GL029979, 2007. 